\title{
Interactions of anthropogenic stress factors on marine phytoplankton
}

\author{
Donat-P. Häder ${ }^{1}$ and Kunshan Gao ${ }^{2 *}$ \\ ${ }^{1}$ Department Biology, Friedrich-Alexander University, Möhrendorf, Germany \\ ${ }^{2}$ State Key Laboratory of Marine Environmental Science, Xiamen University, Xiamen, China
}

\section{Edited by:}

Rajeshwar P. Sinha, Banaras Hindu University, India

Reviewed by:

Madhu Bala Tyagi, Banaras Hindu University, India

Pawan K. Dadheech, Central

University of Rajasthan, India

*Correspondence:

Kunshan Gao, State Key Laboratory of Marine Environmental Science,

Xiamen University (Xiang'An

Campus), Xiang'An, Xiamen,

Fujian 361102, China

e-mail:ksgao@xmu.edu.cn
Phytoplankton are the main primary producers in aquatic ecosystems. Their biomass production and $\mathrm{CO}_{2}$ sequestration equals that of all terrestrial plants taken together. Phytoplankton productivity is controlled by a number of environmental factors, many of which currently undergo substantial changes due to anthropogenic global climate change. Most of these factors interact either additively or synergistically. Light availability is an absolute requirement for photosynthesis, but excessive visible and UV radiation impair productivity. Increasing temperatures enhance stratification and decrease the depth of the upper mixing layer exposing the cells to higher solar radiation and reduce nutrient upward transport from upwelling deeper water. At the same time, stratospheric ozone depletion exposes phytoplankton to higher solar UV-B radiation especially in polar and mid-latitudes. Terrestrial runoff carrying sediments and dissolved organic matter into coastal waters leads to eutrophication while reducing UV penetration. All these environmental forcings are known to affect physiological and ecological processes. Ocean acidification due to increased atmospheric $\mathrm{CO}_{2}$ concentrations changes the seawater chemistry; it reduces calcification in phytoplankton, macroalgae and many zoological taxa. Ocean warming results in changing species composition and favors blooms of toxic prokaryotic and eukaryotic phytoplankton. Increasing pollution from crude oil spills, persistent organic pollutants, heavy metal as well as industrial and household wastewaters affect phytoplankton which is augmented by solar UV radiation. Extensive analyses of the impacts of multiple stressors are scarce. Here, we review reported findings on the impacts of anthropogenic stressors on phytoplankton with an emphasis on their interactive effects and make an effort to provide a prospect for future studies.

Keywords: phytoplankton, UV radiation, nutrients, temperature, global climate change, upper mixing layer, ocean acidification, pollutants

\section{INTRODUCTION}

More than two thirds of our planet is covered by water and more than $99 \%$ of the liquid water are constituted by marine waters (Charette and Smith, 2010). Marine ecosystems are responsible for about half of the biomass production on Earth even though their standing crop represents only about $1 \%$ of the terrestrial biomass (Tardent, 2005; Gruber et al., 2009; Häder et al., 2011). Prokaryotic and eukaryotic phytoplankton are the major primary producers in the oceans, contributing more than $90 \%$ photosynthetic carbon fixation; while macroalgae and seagrasses occupy less than $1 \%$ of oceanic habitats, they also play important roles in carbon cycles in coastal waters. These organisms form the basis of the intricate food webs feeding the subsequent levels of the food web and eventually providing food for the growing human population. The marine ecosystems represent a large carbon sink and sequester an equal amount of $\mathrm{CO}_{2}$ as all terrestrial ecosystems taken together (Falkowski et al., 2000; Zepp et al., 2007), absorbing about 26 million tons of anthropogenically released $\mathrm{CO}_{2}$ per day (Gao et al., 2012b). Therefore, they play a key role in the regulation of the atmospheric $\mathrm{CO}_{2}$ concentration and dampen extreme temperature and weather events (Chester and Jickells, 2012).

Productivity of marine phytoplankton is determined by a number of environmental factors, many of which are influenced by human activities, so that they undergo massive changes due to global climate change, ozone depletion and pollution (Figure 1) (Behrenfeld et al., 2006). One of the major factors affecting primary productivity in phytoplankton is temperature (Lewandowska and Sommer, 2010; Thyssen et al., 2011). Only a few organisms show a positive net photosynthetic activity below freezing (Staehr and Sand-Jensen, 2006; Boyd et al., 2013). Increasing temperatures augment productivity up to a certain optimum beyond which there is a decrease or cessation of active carbon sequestering or death of the organisms, i.e., species are adapted to a thermal window for photosynthetic productivity (Huertas et al., 2011). Mean global temperatures have increased over the last 135 years, as long as systematic measurements exist (Lawrimore et al., 2011). Water temperatures have increased on a global scale due to anthropogenically caused climate change by about $1^{\circ} \mathrm{C}$ over the last 112 years (Fischetti, 2013). Increasing 


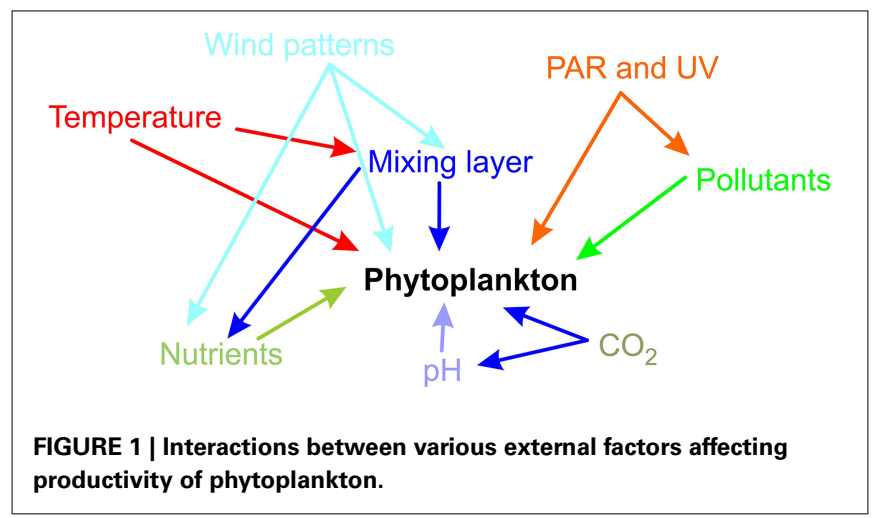

temperatures can also be the cause of deoxygenation especially in coastal and estuarine ecosystems which in extreme cases turn into dead zones for most marine organisms (Howarth et al., 2011; Carstensen et al., 2014).

Regionally, temperature increases can be even much higher; e.g., for the Arctic Ocean a temperature increase of $2^{\circ} \mathrm{C}$ has been recorded over the last 20 years (Forsström, 2006; Economist, 2013), resulting in a substantial loss of ice cover and extension of the growing season (Comiso et al., 2008; Kahru et al., 2010). These dramatic developments caused major changes in species composition and productivity of phytoplankton and the whole food web (Coupel et al., 2012).

Increasing atmospheric $\mathrm{CO}_{2}$ concentrations result in a higher uptake of $\mathrm{CO}_{2}$ into surface waters. The atmospheric $\mathrm{CO}_{2}$ concentration before the onset of the industrial revolution was about $270 \mathrm{ppm}$ (Sigman et al., 2010); today it has exceeded $400 \mathrm{ppm}$ (Solomon, 2007; Kaiser, 2014) and a further rapid increase is being predicted (Meinshausen et al., 2011). Even though the marine waters are well buffered, the $\mathrm{CO}_{2}$ increase has resulted in a global decrease of the $\mathrm{pH}$ by about 0.1 units due to anthropogenically carbon dioxide emitted to the atmosphere (Gao et al., 2012a; Bates et al., 2014). This does not seem dramatic but represents an increase of $30 \%$ in the $\mathrm{H}^{+}$concentrations in the surface waters and further increases are expected to decrease the $\mathrm{pH}$ value by another $0.3-0.4$ units (100-150\% increase in $\mathrm{H}^{+}$concentration) over the next century (Feely et al., 2004). Such progressive ocean acidification is known to affect calcification of calcifying phytoplankton (Beaufort et al., 2011), growth and photosynthesis of many photosynthetic organisms (Wu et al., 2008). While it is almost certain that ocean acidification decreases biogenic calcification, controversial findings on photosynthesis and growth of algae have been documented (Law et al., 2007; Riebesell and Tortell, 2011).

Stratospheric ozone depletion due to anthropogenic production and emission of chlorinated fluorocarbons (CFCs) and other trace gasses (Previdi and Polvani, 2014) resulted in an increasing impact of solar UV-B $(280-315 \mathrm{~nm})$ radiation on the Earth and water surface especially in Polar Regions and at mid-latitudes, while tropical waters are less affected by increasing UV-B radiation scenarios (McKenzie et al., 2011). However, due to the successful implementation of the Montreal Protocol and the subsequent amendments, further ozone depletion could be limited and the UV-B radiation climate is expected to slowly return to normal (pre-1980) levels over the next decades (Ungar, 2012). This slow remediation is due to the long lifetimes of the CFCs up to over 100 years in the stratosphere (Hoffmann et al., 2014). In addition, accumulation in the atmosphere of volatile halocarbons produced and released from algae is known to destroy ozone, resulting in increased incident UV-B radiation at the Earth surface (Law et al., 2007). However, how changing conditions in the ocean caused by global climate change will affect productions of these compounds is unknown.

Light availability in the euphotic zone-the lower limit of which is defined by an attenuation of the surface radiation to $1 \%$ - is determined by the concentration of dissolved and particulate constituents in the water (Häder et al., 2011; Pace et al., 2012). In contrast to open oceanic waters, in coastal areas large amounts of silt and organic material attenuate the incoming radiation especially in the UV band. This material is derived from terrestrial runoff carrying organic matter from decaying vegetation (Yamashita et al., 2013). In addition, organic material from decaying macroalgae and seagrasses contribute to the absorbing substances on the continental shelves (Nelson et al., 2013). Changes in both organic and inorganic dissolved and particulate matter in coastal and open ocean ecosystems have been found to be strongly influenced by human activities (Palleiro et al., 2013).

One of the decisive factors controlling phytoplankton growth is the concentration of available nutrients. In coastal areas most of the nutrients are derived from terrestrial runoff (Fabricius et al., 2013). Increasing discharge of industrial and household wastes as well as fertilizers used in agriculture enhance the mineral loads of rivers (Qu and Kroeze, 2012; Chislock et al., 2013). In open ocean ecosystems wind-blown material contributes $\mathrm{P}, \mathrm{N}$ and Fe among others (Santos, 2010; Biller and Bruland, 2013). Contributions by upwelling waters into the euphotic zone is limited by the lower sharp boundary of the upper mixed layer (UML) called thermocline or pycnocline (Gao et al., 2012b).

Increasing pollution by indiscriminate discharge of heavy metals, pesticides, persistent organic pollutants (POP) (Matthews, 2013)and accidental spills of crude oil products affect phytoplankton in both coastal and open ocean waters (Echeveste et al., 2011; Huang et al., 2011). Many of these key factors additively or synergistically affect phytoplankton productivity. Satellite monitoring of phytoplankton densities, which is available since 1979, indicates that phytoplankton levels have been declining at about $1 \%$ a year over the past half century. A decline over the prior half century is also likely (Boyce et al., 2010). According to simulations by Laufkoetter et al. the biomass of phytoplankton has decreased by $8.5 \%$ from 1960 to 2006 (Laufkoetter et al., 2013). In this review we summarize the effects of major factors determining phytoplankton productivity and highlight the interactions between these effects.

\section{DECREASING STRATOSPHERIC OZONE, UV-B AND EFFECTS ON PHYTOPLANKTON}

Solar radiation hitting the Earth surface can be distinguished into infrared $(>700 \mathrm{~nm})$, visible $(400-700 \mathrm{~nm})$ and UV, which is subdivided into UV-C $(<280 \mathrm{~nm}), \mathrm{UV}-\mathrm{B}(280-315 \mathrm{~nm})$ and UV-A (315-400 nm). UV-C does not penetrate the stratosphere, 
since ozone absorbs radiation below $280 \mathrm{~nm}$ completely; it also absorbs most of the UV-B radiation (Seckmeyer et al., 2008). Anthropogenic emission of chlorinated fluorocarbons and other gaseous pollutants have partially deteriorated the stratospheric ozone layer due to a catalytic effect starting in the 1970s (Lindley, 1988), resulting in increasing UV-B radiation at the Earth surface. This effect is most pronounced in the polar regions but also noticeable at mid-latitudes while in the tropics no significant changes have been measured (McKenzie et al., 2011). The fast rise of solar UV-B was dampened by the Montreal Protocol and subsequent amendments which virtually stopped the production and emission of ozone depleting substances (Egorova et al., 2013; Barnes et al., 2014), so that solar UV-B reaching the Earth surface peaked in the first decade of the current century and is expected to return to pre-1980 levels by about 2065 (United Nations Environment Programme Environmental Effects Assessment Panel, 2012).

Aquatic primary producers need to dwell in the photic zone in order to harvest sufficient solar radiation for their photosynthesis. There they are simultaneously exposed to solar UV radiation. Even though UV-B irradiances amount to only a few percent of UV-A irradiances, they are extremely detrimental since it damages biomolecules and cellular structures (Sinha et al., 2008). UV-B is absorbed by and breaks proteins, membranes and other functional and structural elements of the cell (Sinha et al., 2008), interferes with enzymatic reactions (Walczak, 2008) and impairs physiological responses such as motility and orientation (Ekelund, 1994; Richter et al., 2007). The damage can be induced either by direct hits on cellular targets or by the formation of reactive oxygen species (ROS) such as singlet oxygen $\left({ }^{1} \mathrm{O}_{2}\right)$ (Heck et al., 2003; Zhang et al., 2013). Increasing water temperatures enhance the formation of ROS (Muller et al., 2012).

Photosynthesis of phytoplankton (and other light-harvesting organisms) is specifically vulnerable to solar UV-B radiation. In addition to other targets, short-wavelength radiation hits the D1 protein in the electron transport chain of photosystem II (PS II), which are kinked and the degraded proteins are subsequently removed from their site on the thylakoids (Bouchard et al., 2006). The damage is repaired by replacement with newly synthesized proteins. Increasing water temperatures augment the repair process (Li et al., 2012). In contrast, limiting nutrient availability hampers the repair mechanisms (Doyle et al., 2005). An unexpected finding was that UV-B damages phytoplankton more by impairing the repair mechanism than by the direct damage of the protein (Wu et al., 2012). Decreasing depth of the upper mixing layer (UML) due to stronger stratification induced by increasing temperatures exposes phytoplankton to higher solar UV-B and excessive PAR (photosynthetic active radiation) worsening the effect on the photosynthetic apparatus (Bouchard et al., 2005; Helbling et al., 2005). In contrast, in coastal habitats, increasing concentrations of UV-absorbing substances in the water column, such as dissolved organic material (DOM) and sediment, protect the phytoplankton from excessive exposure to detrimental solar radiation (Fichot et al., 2013). Likewise, increased mixing and vertical circulation in the UML by wind and waves promotes the repair process: when the cells are exposed to solar radiation close to the surface they experience increased damage (Zhou et al.,
2009). This is being repaired when the cells are passively moved to deeper horizons close to the thermocline (lower limit of the UML) (Helbling et al., 2003).

Other targets of solar UV-B in photosynthesis are the accessory pigments which funnel solar energy to the reaction centers. Especially the phycobilins in cyanobacterial cells are affected (Sinha et al., 2005; Six et al., 2007). These pigments are organized in structural elements called phycobilisomes situated on the thylakoids attached to PS II in cyanobacteria and rhodophyta. UV-B was found to first sever the energy transduction to PS II, then disintegrate the phycobilisomes and finally destroy the proteins carrying the phycobilin chromophores (Sinha and Häder, 2003; Sinha et al., 2003).

The DNA in both prokaryotic and eukaryotic organisms is strongly affected by solar UV-B radiation which can penetrate into the water column to ecologically significant depths especially in open ocean waters (Helbling et al., 2005; Meador et al., 2009). There are a large number of UV-B-induced lesions in DNA including single- and double strand breaks, and formation of 64 photoproducts and their Dewar valence isomers; however, the most frequent lesion is the formation of cyclobutane pyrimidine dimers (CPD) (Richa et al., 2014). As in photosynthesis, CPDs are predominantly induced when the cells are close to the surface and repaired when near the thermocline in the UML (Helbling et al., 2008). In addition to excision repair, mismatch repair and SOS response, mainly the photoactivated CPD photolyase is engaged to break the dimers using the energy of UV-A or blue light photons (Cheng et al., 2007; Ioki et al., 2008).

Other mechanisms to avoid or mitigate UV-afflicted damage include active vertical migration by moving out of zones of excessive radiation using flagella or changes in buoyancy, e.g., by production of gas vacuoles or oil vesicles (Overmann and Pfennig, 1992; Ma and Gao, 2009) or by mat formation (Pelletier et al., 2006). With the exception of very small cells (picoplankton) most prokaryotic and eukaryotic phytoplankton use UV-absorbing pigments to block excessive solar UV-B radiation from reaching central regions of the cell such as the nucleus. Scytonemin is exclusively synthesized by cyanobacteria to reduce the impact of UV (Balskus and Walsh, 2008; Rastogi et al., 2013). In addition, they synthesize a variety of mycosporine-like amino acids (MAAs), which are also employed by eukaryotic phytoplankton and number of macroalgae for the same purpose (Singh et al., 2008; Llewellyn et al., 2012). In most cases biosynthesis of MAAs is induced by UV-B exposure (Sinha et al., 1999). Enhanced nutrient availability augments their production and thus provides better protection (Mohovic et al., 2006).

\section{LIGHT PENETRATION INTO THE WATER COLUMN}

Light is the single most important factor for photosynthesis in phytoplankton. The irradiance of solar radiation in the water column is controlled by many atmospheric factors and components in the water (Boss et al., 2007), which govern the transmission and the wavelength distribution (Häder et al., 2007; Smith and Mobley, 2007). The penetration of light into the water is controlled by dissolved organic matter (DOM) and inorganic matter (DIM) (Vione et al., 2009; Xie et al., 2009) as well as by particulate organic (POM) and inorganic matter (PIM) (Mayer et al., 2006; 
Vahatalo and Jarvinen, 2007). Phytoplankton cells contribute to POM, so that the light penetration is controlled by their concentration (Bracchini et al., 2006; Sommaruga and Augustin, 2006). The attenuation of the incoming light can be neutral, i.e., the same percentage at all wavelengths, or it can be higher at specific wavelengths. One fraction of DOM absorbs at shorter wavelengths and is called colored or chromophoric DOM (CDOM) (Osburn et al., 2009).

Eutrophic freshwater ecosystems have much higher DOM concentrations than oligotrophic open ocean systems. Also coastal ecosystems can have high DOM concentrations due to terrestrial runoff and discharge of rivers (Day and Faloona, 2009). The plumes of large rivers can be seen extending sometimes tens to hundreds of kilometers into the sea (Fichot et al., 2013). Most of the DOM is derived from organic material of decaying plant residues (Boyle et al., 2009). High mountain lakes located above the tree line show lower CDOM concentrations because of the lower terrestrial input of organic material and therefore have a higher transparency (Rose et al., 2009). In coastal habitats material from decaying macroalgae which dwell in coastal habitats, contributes to DOM (Hulatt et al., 2007). In open oceanic ecosystems DOM is almost exclusively derived from decaying phytoplankton (Vahatalo and Jarvinen, 2007; Behrenfeld et al., 2009) with the exception of material which stems from decaying swimming macroalgae, as in the Sargasso Sea (Bailey et al., 2008). Since CDOM is produced by the degradation of organic material of terrestrial or marine origin its concentration varies seasonally depending on the time of degradation as well as on rainfall patterns (Suhett et al., 2007). The concentration of CDOM directly and indirectly affect biogeochemical cycles (Zepp et al., 2007; Fernandes et al., 2008).

Extremely high UV-B and UV-A transmissions have been measured in super-oligotrophic waters such as the South Pacific Gyre, where hardly any DOM exists (Tedetti et al., 2007). At $325 \mathrm{~nm}$ $1 \%$ of the surface radiation was found to be transmitted down to $84 \mathrm{~m}$ depth. In the oligotrophic Lake Tahoe (California-Nevada, USA) $1 \%$ of the surface radiation at $320 \mathrm{~nm}$ was measured at $27 \mathrm{~m}$ (Rose et al., 2009) and at $62 \mathrm{~m}$ in the extremely clear Crater Lake (Oregon, USA) (Hargreaves et al., 2007). The light penetration into the water column can be measured with broadband radiometers or spectroradiometers. Furthermore, actinometers based on chemical reactions or damages in DNA have been employed (Schouten et al., 2007, 2009).

In Arctic and Antarctic fresh and marine habitats light availability is attenuated by DOM, POM, DIM, and PIM originating from runoff during ice melting (Schindler and Smol, 2006). Large changes in the transparency occur because of the massive increases in temperature in the Polar Regions by climate change affecting phytoplankton and the subsequent levels in the food web (Keller et al., 2006; Paterson et al., 2008).

The impact of solar UV radiation on CDOM causes a feedback mechanism (Hayakawa and Sugiyama, 2008); CDOM strongly absorbs UV-B which breaks the double bonds. This photodegradation causes a bleaching of these humic substances (Feng et al., 2006; Tzortziou et al., 2007; Zhang et al., 2008). During a cruise in the Bering Sea CDOM levels were found to decrease by $18-55 \%$ when exposed to solar UV-B (Brooks and Lovvorn, 2008). The resulting fragments are easily consumed by bacteria and other microorganisms so that the overall transparency of the water decreases resulting in a deeper penetration of UV-B radiation into the water column (Tedetti et al., 2009), causing detrimental effects on aquatic organisms (Feng et al., 2006). Photodegradation is the key process for mineralization and carbon recycling of DOM (Feng et al., 2006; Anusha and Asaeda, 2008; Wang et al., 2009); the breakdown of plankton and macroalgae biomass releases nutrients such as phosphorous and iron (Shiller et al., 2006; Bastidas Navarro et al., 2009; Bastidas Navarro and Modenutti, 2010). In the presence of DOM dissolved free amino acids are decomposed because of the production of singlet oxygen $\left({ }^{1} \mathrm{O}_{2}\right)$ which has been observed both in Antarctica and in several lakes and rivers in the Northern U.S. (Boreen et al., 2008).

Motile phytoplankton can respond to the ambient light conditions by selecting the vertical position in the water column. Some organisms use active motility such as flagellates (Häder and Griebenow, 1988) while others change their buoyancy by producing gas vacuoles (cyanobacteria) or oil vesicles (diatoms) (Walsby, 1987). Often the motility of phytoplankton is directed by light and gravity. At low light intensities cells often move to the surface using positive phototaxis (Matsunaga et al., 2003) and negative gravitaxis (Eggersdorfer and Häder, 1991; Lebert et al., 1996; Roberts, 2006). When exposed to higher PAR and UV irradiances the cells often switch to negative phototaxis and/or sediment to escape into deeper waters (Lenci et al., 1983; Matsuoka, 1983; Josef et al., 2005). In the open ocean these vertical migrations and orientation mechanisms are often overruled by the action of wind and waves (Helbling et al., 2005; Barbieri et al., 2006) which passively transport the phytoplankton within the mixing layer (Yoshiyama and Nakajima, 2002). However, active movement superimposes the passive mixing so that vertical distribution patterns of phytoplankton can be seen in the water column (Piazena and Häder, 1995).

\section{EFFECTS OF OCEAN ACIDIFICATION AND CHANGES IN SEAWATER CHEMISTRY}

With more and more $\mathrm{CO}_{2}$ building up in the atmosphere, seawater $\mathrm{pCO}_{2}$ increases with increased dissolution of $\mathrm{CO}_{2}$ along with altered seawater carbonate chemistry, as reflected by a drop of $\mathrm{pH}$, increased bicarbonate and decreased carbonate concentrations. Such a progressive ocean acidification also reduces the $\mathrm{CaCO}_{3}$ saturation state. Therefore, calcifying and non-calcifying phytoplankton populations are being affected directly or indirectly due to changed availability of nutrients or forms of different ions. It is predicted that the $\mathrm{pH}$ of the surface oceans will decline by another $0.3-0.4$ units (Orr et al., 2005), increasing $\left[\mathrm{H}^{+}\right]$by $100-150 \%$ by the end of this century. While large scale ocean acidification is superimposed to regional oscillation of $\mathrm{pH}$, phytoplankton as well as other organisms in both pelagic and coastal waters are being affected (Capone and Hutchins, 2014; Waldbusser and Salisbury, 2014).

Phytoplankton species may benefit from increased availability of $\mathrm{CO}_{2}$ or be harmed by the $\mathrm{pH}$ drop, depending on species, levels of other factors or stressors (Gao and Campbell, 2014). Under $800 \mu \mathrm{atm} \mathrm{pCO}_{2}$, growth of diatom-dominated phytoplankton assemblages was not enhanced during $2-5$ days 
shipboard incubation under $\sim 30 \%$ of incident sunlight (Tortell, 2000). In the diatom Skeletonema costatum, growth was not stimulated by an enriched $\mathrm{CO}_{2}$ concentration $(800 \mu \mathrm{atm})$ under laboratory conditions (Burkhardt and Riebesell, 1997; Chen and Gao, 2003, 2004), but was enhanced in a mesocosm at an elevated $\mathrm{CO}_{2}$ concentration of $750 \mu \mathrm{atm}$ (Kim, 2006). For the diatoms Phaeodactylum tricornutum (Schippers et al., 2004; Wu et al., 2010), Navicula pelliculosa (Low-Décarie et al., 2011), and Attheya sp. (King et al., 2011), growth was enhanced under elevated $\mathrm{CO}_{2}$ levels under laboratory conditions. When the diatoms S. costatum (CCMA110), P. tricornutum (CCMA 106) and Thallasiora pseudonana (CCMP 1335) were grown under different levels of sunlight and elevated $\mathrm{CO}_{2}$ of $1000 \mu \mathrm{atm}$, their growth was stimulated under lower light levels (5-30\% surface daytime mean solar PAR), but inhibited under higher light levels (Gao et al., 2012a). These results show that elevated $\mathrm{CO}_{2}$ and light levels interact affecting diatom growth responses to ocean acidification. However, such interaction was not observed in the coccolithophore Emiliania huxleyi (Jin, Gao et al. unpublished data). Ocean acidification may increase (Wu et al., 2010; Yang and Gao, 2012) or decrease (Hennon et al., 2014) mitochondrial respiration, increase photorespiration (Gao et al., 2012b; Xu and Gao, 2012) and influence the photophysiology of phytoplankton (Gao and Campbell, 2014). In the South China Sea, surface phytoplankton assemblages were found to assimilate less carbon either based on chl $a$ or based on per volume of seawater under elevated $\mathrm{CO}_{2}$ levels of 800 or $1000 \mu$ atm, with their nonphotochemical (Figure 2) (Gao et al., 2012b), after acclimation to the $\mathrm{CO}_{2}$-induced acidification for about a week. Such a phenomenon reflects the balanced net outcome of photosynthetic carbon fixation and respiratory carbon loss associated with seawater acidification and the enhanced regulation of thermal energy dissipation (Gao et al., 2012b).

Recently, across a $\mathrm{CO}_{2} / \mathrm{pH}$ gradient off the volcanic island of Vulcano (NE Sicily), periphyton communities altered significantly as $\mathrm{CO}_{2}$ concentrations increased, with significant increases in chlorophyll a concentrations and in diatom abundance (Johnson et al., 2013). This implies a possibility that the "winners" could have increased their photosynthetic antenna to capture additional light energy to cope with the extra energy demand (such as enhanced respiration) due to increased seawater acidity. These inconsistent or controversial findings can be attributed to different experimental setups or environmental conditions or species-specific physiology (Langer et al., 2006, 2009; Gao et al., 2012a; Hutchins et al., 2013; Schaum et al., 2013). Molecular changes leading to an altered physiology and subsequently to changed ecology level responses of different phytoplankton taxa are expected to be seen in the near future. At the same time, our present understanding of potential ocean acidification impacts is almost entirely limited to single species responses, species competition and phytoplankton community changes with ocean acidification remain poorly understood (Rossoll et al., 2012; Calbet et al., 2014).

In waters of low $\mathrm{pH}$ or hypoxia or upwelling areas, low $\mathrm{pH}$ values coincide with low dissolved oxygen (DO), which mirrors acidification and deoxygenation; net photosynthetic production may inversely relate to the ratio of $\mathrm{DO}$ to $\mathrm{pCO}_{2}$ (Gao and

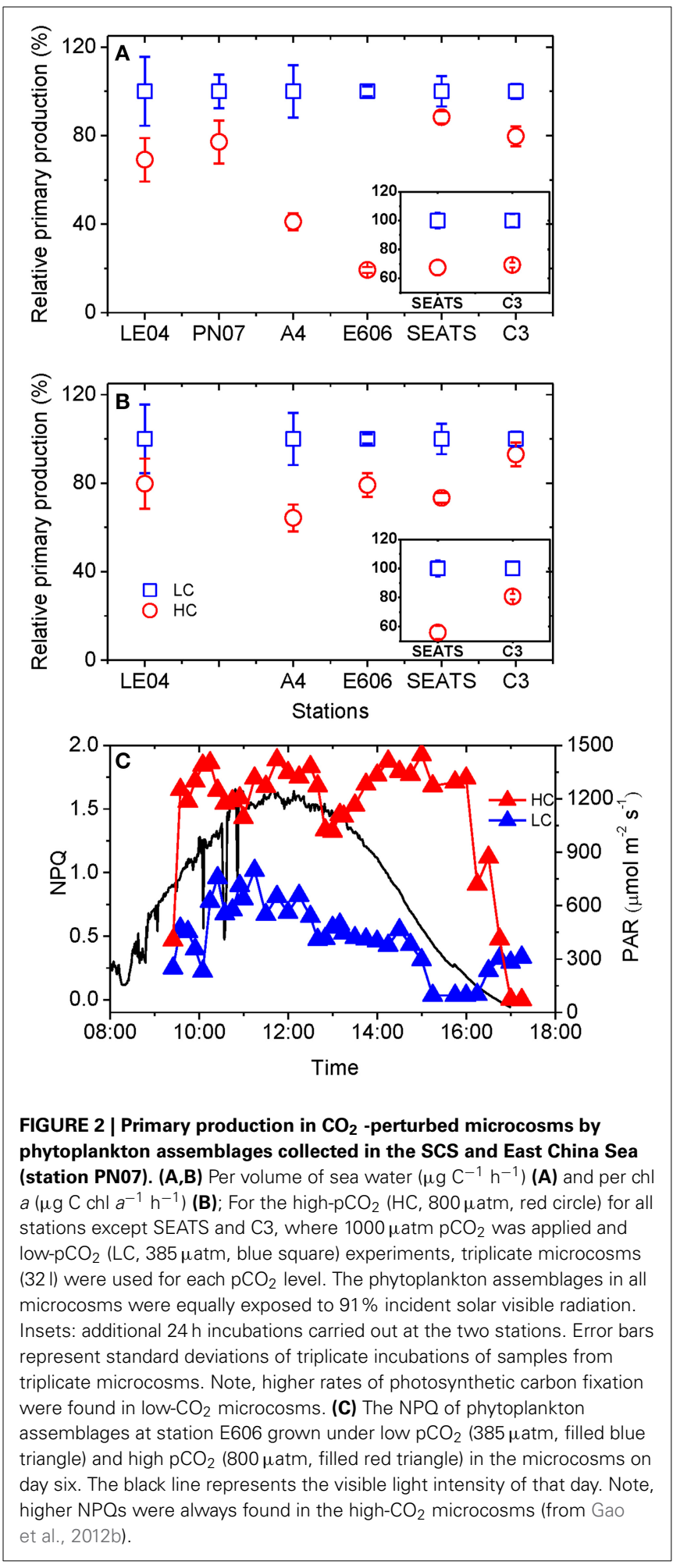

Campbell, 2014). While the exchanges of $\mathrm{O}_{2}$ and $\mathrm{CO}_{2}$ during photosynthesis or respiration can be affected by the external ratio of DO to $\mathrm{pCO}_{2}$ (Flynn et al., 2012), thickness of diffusion layers around the phytoplankton cells depends on physical processes, such as mixing or stirring, therefore, effects of increased $\mathrm{pCO}_{2}$ or 
decreased DO would be altered by physical processes. Since stratification leads to future shoaling of upper-mixed-layer (UML) depths, phytoplankton cells are exposed to increasing solar irradiances with reduced mixing pathlength; therefore, interaction of physical and chemical environmental forcings will determine phytoplankton physiological performances and their ecological roles. A recent study showed that frequencies of light fluctuation that mimic different mixing regimes affect a coccolithophore's response to ocean acidification (Jin et al., 2013). In comparison, diatoms grown under fluctuating light decreased their growth and altered their responses to elevated $\mathrm{CO}_{2}$ in contrast to those under constant light regimes (Gao et al., 2012b). Obviously, effects of ocean acidification can differ under indoor constant conditions from those under incident solar radiation (Gao et al., 2012b), which could impose an additional interaction on the net species and community responses to increasing $\mathrm{pCO}_{2}$.

\section{EFFECTS OF OCEAN WARMING}

The accumulated $\mathrm{CO}_{2}$ in the atmosphere traps heat reflected as infrared radiation $(>700 \mathrm{~nm})$ and both terrestrial and aquatic ecosystems are thus being warmed. Although global mean sea surface temperatures are increasing at about half the pace of those on land, 0.13 vs. $0.27^{\circ} \mathrm{C}$ per decade since 1979 , ocean warming is one of the strongest anthropogenic forcing on primary and secondary production in marine systems (Halpern et al., 2008). Warming trends are suggested to alter distributions of major phytoplankton groups (Thomas et al., 2012), such as dinoflagellates (Hallegraeff, 2010; Fu et al., 2012), diatoms, coccolithophorides (Mericoa et al., 2004; Hare et al., 2007) and cyanobacteria (Breitbarth et al., 2007; Pittera et al., 2014). It was reported that rising temperatures in this century will cause pole-ward shifts in species' thermal niches and a sharp decline in tropical phytoplankton diversity in the absence of an evolutionary response (Thomas et al., 2012). A 50-year (1960-2009) time series survey revealed a decline of dinoflagellate abundance in the northeast Atlantic and North Sea, but this was not observed in the abundance of diatoms (Hinder et al., 2012). For a long time marine scientists have hinted that phytoplankton levels were decreasing, but no systematic, worldwide account of their decline had been made. Boyce et al. showed that phytoplankton levels have been declining on a global scale at about $1 \%$ a year over the past half century (Boyce et al., 2010). Ocean warming and consequent stratification as well as other ocean changes (such as ocean acidification, thermocline/nutricline changes) would be responsible for such observed declines.

Pelagic and coastal waters exhibit different scales of day/night temperature changes, being larger in the latter; different latitudes have differences in annual and daily temperature means and ranges. Therefore, marine phytoplankton cells are subjected to substantial changes of temperature on different time scales. These include rapid shifts associated with tides, diurnal and seasonal fluctuations caused by clouds and changes in solar elevation and long-term, inter-annual variability associated with natural climatic cycles and likely, human influence. These changes in temperature can influence the thermal windows of marine organisms by influencing their enzymatic efficiency and heat tolerance (Pörtner and Farrell, 2008).
For photosynthetic organisms, photosynthesis usually increases with increased temperature to reach an optimum and then declines with further warming, while respiration increases with increasing temperatures. Elevated temperature increases growth (Feng et al., 2008; Arnold et al., 2013; Sett et al., 2014), photosynthesis (Feng et al., 2008; Xu et al., 2011; Müller et al., 2014) and calcification (Xu et al., 2011; Müller et al., 2014) of coccolithophores. There is also growing evidence showing that elevated temperature had a positive impact on the photosynthesis of other phytoplankton taxa, such as diatoms ( $\mathrm{Li}$ et al., 2012) and cyanobacteria (Fu et al., 2007, 2014). A recent study demonstrated that elevated temperatures $\left(+6^{\circ} \mathrm{C}\right)$ increased the phytoplankton biomass in natural plankton communities (Lewandowska et al., 2014). A combination of elevated temperature and increased $\mathrm{CO}_{2}$ levels acted synergistically to increase the growth of phytoplankton (Connell and Russell, 2010; Fiorini et al., 2011); however, no interactive effects of these two factors were reported in some previous studies (Hutchins et al., 2007; Feng et al., 2008). The combination of elevated temperature and $\mathrm{CO}_{2}$ levels acted synergistically to raise the repair rate of the PSII machinery damaged by UV radiation (Li et al., 2012). The respiration coefficient $\left(T_{10}\right.$, change in respiration rate induced by a $10^{\circ} \mathrm{C}$ temperature change) may increase under ocean acidification conditions in algae (Zou et al., 2011). While respiration increased by over $30 \%$ in the diatoms Phaeodactylum tricornutum and Thallasiora pseudonana at $1000 \mu \mathrm{atm} \mathrm{pCO}_{2}$, combined effects of ocean acidification and warming on phytoplankton respiration have little been documented. Since both photosynthesis and respiration will likely be influenced by ocean warming and ocean acidification, but probably to a different extent, the ratio of photosynthetic carbon fixation to respiratory carbon loss within the euphotic zone will vary in future warmer and acidified oceans. Two strains of the marine picocyanobacteria Synechococcus and Prochlorococcus responded differentially to warming as well as to elevated $\mathrm{CO}_{2}$, with the growth rate of the former increasing and that of the latter not changing under the combined "greenhouse" treatment (Fu et al., 2007). Growth and nitrogen fixation rates of two isolates of the filamentous cyanobacterium Trichodesmium were strongly enhanced by either increasing $\mathrm{CO}_{2}(750 \mu \mathrm{atm})$ or a $4^{\circ} \mathrm{C}$ temperature increase, but synergistic effects between the two variables were not observed (Hutchins et al., 2007). Levitan et al. reported similar findings for these two parameters in one of these same Trichodesmium isolates under the combination of warmer temperature $\left(+6^{\circ} \mathrm{C}\right)$ and higher $\mathrm{CO}_{2}(900 \mu \mathrm{atm})$ (Levitan et al., 2010). In contrast, in an experiment using a mixed natural North Atlantic bloom community, coccolithophore cell abundance was greatly increased under the "greenhouse" combination of increased $\mathrm{pCO}_{2}$ and temperature, but not when either one was increased alone (Feng et al., 2009). Obviously, responses of most phytoplankton species studied under elevated $\mathrm{CO}_{2}$ are temperature dependent. In the coccolithophorides, Emiliania huxleyi and Gephyrocapsa oceanica, at the optimal levels of $\mathrm{CO}_{2}$ concentration for growth, calcification and carbon fixation rates are modulated by temperature, with the optimum temperature level increased under elevated $\mathrm{CO}_{2}$ concentrations (Sett et al., 2014). Recent culture work, however, showed that two strains of the coccolithophore E. huxleyi were unable to 
adapt to pronounced warming to $30^{\circ} \mathrm{C}$ (Huertas et al., 2011). Further studies looking at the potential for long-term adaptation of phytoplankton to higher temperatures is needed, especially in combination with acidification and other global change variables.

\section{NUTRIENTS}

Phytoplankton productivity in most of the world's oceans is limited by the availability of nutrients, including nitrogen, iron and phosphorus, in the euphotic zone. Especially large areas of the tropics and subtropics are characterized by nitrogen depletion (Beman et al., 2005). Microbial denitrification decreases available stocks of nitrogen from the water column even though cyanobacteria enhance nitrogen resources since these prokaryotes are capable of fixing atmospheric nitrogen, using the enzyme nitrogenase, and make it available to eukaryotic phytoplankton (Bergman, 1999; Mulholland and Capone, 2000). However, in coastal areas, agricultural runoff spikes large phytoplankton blooms stretching over many square kilometers such as in the Gulf of California (Beman et al., 2005, 2011). Also rivers are often subject to increased nutrient concentrations due to runoff of fertilizers from adjacent fields to a point that they must be considered as pollution. This eutrophication deteriorates the water quality and affects consumers higher up in the food web (Hutchins et al., 2010).

Also estuaries are affected by increased nutrient concentrations. Phytoplankton species composition, their abundance and diurnal and spatial distribution were studied in the Changjiang Estuary. Increasing phosphorous concentrations were identified as causing blooms with an average cell density of $6.75 \times 10^{5}$ cells $\mathrm{l}^{-1}$ of dominant phytoplankton species such as Prorocentrum dentatum and Skeletonema costatum which is much higher than cell counts in previous years.

Increasing temperatures and enhanced nutrient supply support the occurrence of harmful algal blooms, which are often formed by dinoflagellates. El Niño events and changes in the North Atlantic Oscillation promote the cell density of these phytoplankton by altering stratification, ocean currents and nutrient availability as fossil records of dinoflagellate cysts have indicated (Hallegraeff, 2010). Also with limited inorganic nitrogen supply blooms of toxic algae can develop fueled by a large pool of dissolved organic nitrogen (DON) (Bronk et al., 2007). Upwelling of submarine groundwater can be another source of nitrogen (Paytan et al., 2006).

Nitrogen shortage results in reduced biomass synthesis and decreased production of sulfur compounds such as DMS, DMSP, and DMSO (Harada et al., 2009). Phosphate limitation affects alkaline phosphatase activity in phytoplankton and bacteria (Labry et al., 2005). Cyanobacteria such as Microcystis can also produce harmful and toxic plankton blooms which deteriorate drinking water reservoirs and potentially threaten animal and human health (Oberholster et al., 2004). In some habitats like recreationally used rivers and lakes the occurrence of algal blooms is regarded as a nuisance. Recent discussions how to limit the development of these blooms include reduction of nutrient pollution as opposed to riparian shading (Hutchins et al., 2010).

\section{POLLUTANTS}

The increasing environmental pollution is another anthropogenic stress factor which affects phytoplankton. Especially coastal areas and freshwater habitats are affected. However, sewage, even at high concentrations does not seem to negatively affect phytoplankton. A study of the Cauvery river, Tamil Nadu, India, showed high concentrations of phytoplankton and zooplankton even though the river is highly contaminated with household and industrial effluents (Mathivanan et al., 2007). In contrast, a multivariate analysis of one of the most polluted rivers in Latin America (Reconquista River, Buenos Aires Province, Argentina) showed strong inhibition of the phytoplankton populations due to agrochemicals as well as domestic and industrial untreated effluents (Olguín et al., 2004). But the water quality changed seasonally. High concentrations of pollutants and nutrients ammonium and orthophosphates, high BOD, hardness and conductivity favored the dominance of a single algal species, while better water quality resulted in higher algal and crustacean diversity. Analysis of the phytoplankton communities can be used to determine the water quality polluted by industrial effluents as shown at the downstream stretch of the Bhadra river (Shashi Shekhar et al., 2008). Heavy metal pollution is often found in lakes and rivers in developing countries affecting phytoplankton productivity (Oberholster et al., 2010). This has recently been summarized for many freshwater ecosystems in Pakistan (Azizullah et al., 2011).

Fluorescence of chlorophyll $a$ was used as an endpoint for monitoring of the ecotoxicological effectiveness of atrazine, which is used as a herbicide since it inhibits the photosynthetic electron transport chain (Seguin et al., 2002). Phytoplankton isolated from Lake Geneva (Switzerland) showed signs of inhibition at atrazine concentrations of $10 \mu \mathrm{g} / \mathrm{L}$. However, the phytoplankton could adapt to the herbicide stress since a 25 days exposure to $30 \mu \mathrm{g} / \mathrm{L}$ of atrazine significantly increased the tolerance of the organisms.

Crude oil spills affect phytoplankton especially in shallowwater marine habitats such as the Arctic Ocean. Water-soluble fractions of heavy oil such as pyrene are the most toxic ones; pyrene accumulates in the sediment. Exposure to solar UV-B and increasing temperatures worsen the toxicity (Grenvald et al., 2013). Oil exploration will increase in many coastal habitats such as Western Greenland (Hylander et al., 2014). The impact of oil pollution on growth rates and physiological activities has been studied in phytoplankton assemblages in the river Nile (Egypt), comparing a polluted with a non-polluted site (El-Sheekh et al., 2000). Both crude oil and its refinery products affect growth, proteins and nucleic acids: at low concentrations these pollutants augment the physiological performance but at higher concentrations they are inhibitory; however different species show different sensitivities.

Polychlorinated biphenyls (PCBs) are a major problem in both marine and freshwater ecosystems. Since they are lipophilic they can easily penetrate the cell membranes of phytoplankton resulting in substantial bioconcentration as shown in four marine phytoplankton species sampled in the Baltic Sea (Gerofke et al., 2005). PCBs also play a role in the air-water exchange and vertical fluxes. A simulation showed that air-water exchange controls PCB concentrations in phytoplankton in remote environments which are not directly affected by terrigenous pollution (Dachs et al., 
2000). Persistent organic pollutants (POP) accumulate in phytoplankton as was found recently during a cruise in the Greenland Current and Arctic Ocean (Galbán-Malagón et al., 2012). Both phytoplankton and bacteria are involved in the biogeochemical cycling of POPs. Being organic, these substances are easily taken up by the cells; this process depends on the ambient temperature, the cell size and the hydrophobicity of POPs. In addition to PCBs, polycyclic aromatic hydrocarbons (PAHs), polychlorinated dioxins and furans (PCDD/Fs), as well as polybrominated diphenyl ethers (PBDEs) are of major concern as pollutants affecting phytoplankton (Del Vento and Dachs, 2002). Marine biogeochemical mechanisms are key in controlling the global dynamics and control the final sink of POPs (Dachs et al., 2002; Gang and Xitao, 2005).

UV exposure increases the toxicity of many pollutants such as PAHs derived from combustion engines, augmenting the stress in inland and coastal marine environments. This was confirmed by investigations in natural phytoplankton assemblages from the Mediterranean Sea, Atlantic, Arctic and Southern Ocean (Echeveste et al., 2011). Pre-stressed with UV-B, natural phytoplankton communities are more sensitive to pollutants such as atrazine, tributyltin or crude oil which enter coastal waters from terrestrial drainage or maritime traffic than those grown when UV is excluded. Antifouling paints for vessels in aquatic environments contain biocides. More recent developments aim at formulating substances which rapidly degrade when they are released from ship hulls. One of the recently developed components is 4,5-dichloro-2-n-octyl-isothiazoline-3-one (DCOI) (Bérard and Benninghoff, 2001).

Species diversity is a good measure for ecosystem functioning and the stress exerted by environmental pollutants. Model studies of freshwater and brackish ecosystems show a positive relationship between nutrient levels, such as phosphorous, pollutant concentrations and carbon uptake by phytoplankton. Pollutionmediated losses of phytoplankton diversity may have direct detrimental effects on the aquatic primary production (Ptacnik et al., 2008).

\section{CONCLUSIONS AND FUTURE WORK}

The anthropogenic environmental forcings can act interactively to result in harmful, neutral or in some regions stimulating effects on phytoplankton species. Species competition under different environmental settings often differs due to species-specific physiological responses. Nutrients, such as nitrogen, phosphorus and iron, are key elements that limit primary production by marine phytoplankton. The concentrations of these elements usually vary according to regional environmental changes and therefore may affect the physiological and ecological responses of phytoplankton to the anthropogenic stressors, such as ocean acidification and warming and UV-B irradiances. Decreased $\mathrm{pH}$ and increased temperature are known to interact with UV radiation to influence photosynthesis and/or growth of typical phytoplankton species (Gao et al., 2012a; Li et al., 2012). Increased light exposure or fluctuating irradiances of light can also interact with ocean acidification to affect photosynthetic carbon fixation of phytoplankton. How these multivariate feedbacks may change in the oceans under climate change conditions remains speculative.
Ocean warming associated with global warming enhances stratification (reduces the thickness of the upper mixing layer) and decreases nutrient availability due to reduced upward transport of nutrients from deeper layers. Therefore, stratification increases UV exposure of phytoplankton cells circulating in a shallower mixed layer (Gao et al., 2012a). Increased UV exposures can lead to more damages to phytoplankton cells, including decreased contents of photosynthetic pigments and increased damages to DNA and proteins of phytoplankton. Therefore, climate change-driven ocean changes may lead to different biogeochemical outcomes.

Which effects these anthropogenic environmental forcings have has to be considered in a holistic context. Most of the studies so far have been conducted under laboratory conditions without considering multiple factors (Gao et al., 2012a). This is one of the main limitations in our knowledge of phytoplankton community transition as well as their nutritious changes under the global change factors in the real oceans. The relations of changes in PAR and temperature to phytoplankton species in the oceans are obvious; however, few phytoplankton studies have addressed their physiological and ecological interactions with high $\mathrm{CO}_{2}$ and lower $\mathrm{pH}$ in the presence of other stressors. Additionally, effects of solar UVR have not been taken into account in laboratory experiments due to the common use of UV-free light sources. Experimental tests of the impacts of anthropogenic stressors under real sunlight or more realistic conditions would allow more reliable predictions of effects of future ocean changes on marine primary production.

\section{ACKNOWLEDGMENTS}

Part of this study was supported National Natural Science Foundation (No. 41430967; 41120164007), Joint project of NSFC and Shandong province (Grant No. U1406403), Strategic Priority Research Program of CAS (Grant No. XDA11020302), SOA (GASI-03-01-02-04) and China-Japan collaboration project from MOST (S2012GR0290).

\section{REFERENCES}

Anusha, K., and Asaeda, T. (2008). Indirect mechanisms accelerated due to ultraviolet-B irradiation on nutrient cycling in a freshwater ecosystem. J. Photochem. Photobiol. B 93, 1-8. doi: 10.1016/j.jphotobiol.2008. 06.009

Arnold, H. E., Kerrison, P., and Steinke, M. (2013). Interacting effects of ocean acidification and warming on growth and DMS-production in the haptophyte coccolithophore Emiliania huxleyi. Glob. Change Biol. 19, 1007-1016. doi: $10.1111 /$ gcb. 12105

Azizullah, A., Richter, P., and Häder, D. (2011). Ecotoxicological evaluation of wastewater samples from Gadoon Amazai Industrial Estate (GAIE), Swabi, Pakistan. Int. J. Environ. Sci. Technolo. 1, 1-17.

Bailey, K. E., Toole, D. A., Blomquist, B., Najjar, R. G., Huebert, B., Kieber, D. J., et al. (2008). Dimethylsulfide production in Sargasso Sea eddies. Deep Sea Res. Part II 55, 1491-1504. doi: 10.1016/j.dsr2.2008.02.011

Balskus, E. P., and Walsh, C. T. (2008). Investigating the initial steps in the biosynthesis of cyanobacterial sunscreen scytonemin. J. Am. Chem. Soc. 130, 15260-15261. doi: 10.1021/ja807192u

Barbieri, E. S., Villafañe, V. E., and Helbling, E. W. (2006). Dynamics of oxygen production/consumption in Dunaliella salina, Thalassiosira weissflogii and Heterocapsa triqueta circulating within a simulated upper mixed layer. Investigaciones Marinas 24, 97-108.

Barnes, E. A., Barnes, N. W., and Polvani, L. M. (2014). Delayed Southern Hemisphere climate change induced by stratospheric ozone recovery, as 
projected by the CMIP5 models. J. Clim. 27, 852-867. doi: 10.1175/JCLI-D-1300246.1

Bastidas Navarro, M., Balseiro, E., and Modenutti, B. (2009). Effect of UVR on lake water and macrophyte leachates in shallow Andean-Patagonian lakes: bacterial response to changes in optical features. Photochem. Photobiol. 85, 332-340. doi: 10.1111/j.1751-1097.2008.00442.x

Bastidas Navarro, M., and Modenutti, B. (2010). UVR induce optical changes and phosphorous release of lake water and macrophyte leachates in shallow Andean lakes. J. Limnol. 69. doi: 10.4081/jlimnol.2010.112

Bates, N., Astor, Y., Church, M., Currie, K., Dore, J., Gonaález-Dávila, M., et al. (2014). A time-series view of changing ocean chemistry due to ocean uptake of anthropogenic $\mathrm{CO}_{2}$ and ocean acidification. Oceanography 27, 126-141. doi: 10.5670/oceanog.2014.16

Beaufort, L., Probert, I., De Garidel-Thoron, T., Bendif, E. M., Ruiz-Pino, D., Metzl, N., et al. (2011). Sensitivity of coccolithophores to carbonate chemistry and ocean acidification. Nature 476, 80-83. doi: 10.1038/ nature 10295

Behrenfeld, M. J., Westberry, T. K., Boss, E. S., O’Malley, R. T., Siegel, D. A., Wiggert, J. D., et al. (2009). Satellite-detected fluorescence reveals global physiology of ocean phytoplankton. Biogeosciences 6, 779-794. doi: 10.5194/bg-6779-2009

Behrenfeld, M., O’Malley, R., Siegel, D., McClain, C., Sarmiento, J., Feldman, G., et al. (2006). Climate-driven trends in contemporary ocean productivity. Nature 444, 752-755. doi: 10.1038/nature05317

Beman, J. M., Arrigo, K. R., and Matson, P. A. (2005). Agricultural runoff fuels large phytoplankton blooms in vulnerable areas of the ocean. Nature 434, 211-214. doi: 10.1038/nature03370

Beman, J. M., Chow, C.-E., King, A. L., Feng, Y., Fuhrman, J. A., Andersson, A., et al. (2011). Global declines in oceanic nitrification rates as a consequence of ocean acidification. Proc. Natl. Acad. Sci. U.S.A. 108, 208-213. doi: 10.1073/pnas. 1011053108

Bérard, A., and Benninghoff, C. (2001). Pollution-induced community tolerance (PICT) and seasonal variations in the sensitivity of phytoplankton to atrazine in nanocosms. Chemosphere 45, 427-437. doi: 10.1016/S0045-6535(01) 00063-7

Bergman, B. (1999). "Distribution of nitrogenase in the marine non-heterocystous cyanobacterium Trichodesmium-a review," in Marine Cyanobacteria, eds L. Charpy and A. W. D. Larcum (Monaco: Bulletin de l' Institut Oceanographique), 223-227.

Biller, D. V., and Bruland, K. W. (2013). Sources and distributions of Mn, Fe, Co, $\mathrm{Ni}, \mathrm{Cu}, \mathrm{Zn}$, and Cd relative to macronutrients along the central California coast during the spring and summer upwelling season. Mar. Chem. 155, 50-70. doi: 10.1016/j.marchem.2013.06.003

Boreen, A. L., Edhlund, B. L., Cotner, J. B., and McNeill, K. (2008). Indirect photodegradation of dissolved free amino acids: the contribution of singlet oxygen and the differential reactivity of DOM from various sources. Environ. Sci. Technol. 42, 5492-5498. doi: 10.1021/es800185d

Boss, E. S., Collier, R., Larson, G., Fennel, K., and Pegau, W. S. (2007). Measurements of spectral optical properties and their relation to biogeochemical variables and processes in Crater Lake, Crater Lake National Park, OR. Hydrobiologia 574, 149-159. doi: 10.1007/s10750-006-2609-3

Bouchard, J. N., Roy, S., and Campbell, D. A. (2006). UVB effects on the photosystem II-D1 protein of phytoplankton and natural phytoplankton communities. Photochem. Photobiol. 82, 936-951. doi: 10.1562/2005-08-31-IR-666

Bouchard, J. N., Roy, S., Ferreyra, G., Campbell, D. A., and Curtosi, A. (2005). Ultraviolet-B effects on photosystem II efficiency of natural phytoplankton communities from Antarctica. Polar Biol. 28, 607-618. doi: 10.1007/s00300005-0727-4

Boyce, D. G., Lewis, M. R., and Worm, B. (2010). Global phytoplankton decline over the past century. Nature 466, 591-596. doi: 10.1038/ nature09268

Boyd, P. W., Rynearson, T. A., Armstrong, E. A., Fu, F., Hayashi, K., Hu, Z., et al. (2013). Marine phytoplankton temperature versus growth responses from polar to tropical waters-Outcome of a scientific community-wide study. PLoS ONE 8:e63091. doi: 10.1371/journal.pone.0063091

Boyle, E. S., Guerriero, N., Thiallet, A., Del Vecchio, R., and Blough, N. V. (2009). Optical properties of humic substances and CDOM: relation to structure. Environ. Sci. Technol. 43, 2262-2268. doi: 10.1021/es803264g
Bracchini, L., Dattilo, A. M., and Hull, V. (2006). The bio-optical properties of CDOM as descriptor of lake stratification. J. Photochem. Photobiol. B 85, 145-149. doi: 10.1016/j.jphotobiol.2006.06.003

Breitbarth, E., Oschlies, A., and Laroche, J. (2007). Physiological constraints on the global distribution of Trichodesmium-Effect of temperature on diazotrophy. Biogeosciences 4, 53-61. doi: 10.5194/bg-4-53-2007

Bronk, D., See, J., Bradley, P., and Killberg, L. (2007). DON as a source of bioavailable nitrogen for phytoplankton. Biogeosciences 4, 283-296. doi: 10.5194/bg-4283-2007

Brooks, M. L., and Lovvorn, J. R. (2008). "Surprising results of CDOM photooxidation in the Bering Sea: implications for food webs," in Ocean Sciences Meeting (Orlando, FL, Session \# 162).

Burkhardt, S., and Riebesell, U. (1997). $\mathrm{CO}_{2}$ availability affects elemental composition (C: N: P) of the marine diatom Skeletonema costatum. Mar. Ecol. Prog. Ser. 155, 67-76. doi: 10.3354/meps 155067

Calbet, A., Sazhin, A. F., Nejstgaard, J. C., Berger, S. A., Tait, Z. S., Olmos, L., et al. (2014). Future climate scenarios for a coastalpProductive planktonic food web resulting in microplankton phenology changes and decreased trophic transfer efficiency. PLoS ONE 9:e94388. doi: 10.1371/journal.pone.0094388

Capone, D. G., and Hutchins, D. A. (2014). Microbial biogeochemistry of coastal upwelling regimes in a changing ocean. Nat. Geosci. 6, 711-717. doi: 10.1038/ngeo 1916

Carstensen, J., Andersen, J. H., Gustafsson, B. G., and Conley, D. J. (2014). Deoxygenation of the Baltic Sea during the last century. Proc. Natl. Acad. Sci. U.S.A. 111, 5628-5633. doi: 10.1073/pnas.1323156111

Charette, M. A., and Smith, W. H. F. (2010). The volume of Earth's Ocean. Oceanography 23, 112-114. doi: 10.5670/oceanog.2010.51

Chen, X., and Gao, K. (2003). Effect of $\mathrm{CO}_{2}$ concentrations on the activity of photosynthetic $\mathrm{CO}_{2}$ fixation and extracelluar carbonic anhydrase in the marine diatom Skeletonema costatum. Chin. Sci. Bull. 48, 2616-2620. doi: $10.1360 / 03$ wc0084

Chen, X., and Gao, K. (2004). Characterization of diurnal photosynthetic rhythms in the marine diatom Skeletonema costatum grown in synchronous culture under ambient and elevated $\mathrm{CO}_{2}$. Funct. Plant Biol. 31, 399-404. doi: 10.1071/FP03240

Cheng, L., Qiao, D. R., Lu, X. Y., Xiong, Y., Bai, L. H., Xu, H., et al. (2007). Identification and expression of the gene product encoding a CPD photolyase from Dunaliella salina. J. Photochem. Photobiol. B 87, 137-143. doi: 10.1016/j.jphotobiol.2007.01.002

Chester, R., and Jickells, T. (2012). Marine Geochemistry. Chichester: WileyBlackwell.

Chislock, M. F., Doster, E., Zitomer, R. A., and Wilson, A. (2013). Eutrophication: causes, consequences, and controls in aquatic ecosystems. Nat. Edu. Knowledge 4,10 .

Comiso, J. C., Parkinson, C. L., Gersten, R., and Stock, L. (2008). Accelerated decline in the Arctic sea ice cover. Geophys. Res. Lett. 35:L01703. doi: 10.1029/2007GL031972

Connell, S. D., and Russell, B. D. (2010). The direct effects of increasing $\mathrm{CO}_{2}$ and temperature on non-calcifying organisms: increasing the potential for phase shifts in kelp forests. Proc. Biol. Soci. B 277, 1409-1415. doi: 10.1098/rspb.2009.2069

Coupel, P., Jin, H. Y., Joo, M., Horner, R., Bouvet, H. A., Sicre, M.-A., et al. (2012). Phytoplankton distribution in unusually low sea ice cover over the Pacific Arctic. Biogeosciences 9, 4835-4850. doi: 10.5194/bg-9-4835-2012

Dachs, J., Eisenreich, S. J., and Hoff, R. M. (2000). Influence of eutrophication on air-water exchange, vertical fluxes, and phytoplankton concentrations of persistent organic pollutants. Environ. Sci. Technol. 34, 1095-1102. doi: $10.1021 / \mathrm{es} 990759 \mathrm{e}$

Dachs, J., Lohmann, R., Ockenden, W. A., Méjanelle, L., Eisenreich, S. J., and Jones, K. C. (2002). Oceanic biogeochemical controls on global dynamics of persistent organic pollutants. Environ. Sci. Technol. 36, 4229-4237. doi: 10.1021/es02 $5724 \mathrm{k}$

Day, D. A., and Faloona, I. (2009). Carbon monoxide and chromophoric dissolved organic matter cycles in the shelf waters of the northern California upwelling system. J. Geophys. Res. Oceans 114, 18. doi: 10.1029/2007JC004590

Del Vento, S., and Dachs, J. (2002). Prediction of uptake dynamics of persistent organic pollutants by bacteria and phytoplankton. Environ. Toxicol. Chem. 21, 2099-2107. doi: 10.1002/etc.5620211013 
Doyle, S. A., Saros, J. E., and Williamson, C. E. (2005). Interactive effects of temperature and nutrient limitation on the response of alpine phytoplankton growth to ultraviolet radiation. Limnol. Oceanogr. 50, 1362-1367. doi: 10.4319/lo.2005.50.5.1362

Echeveste, P., Agustí, S., and Dachs, J. (2011). Cell size dependence of additive versus synergetic effects of UV radiation and PAHs on oceanic phytoplankton. Environ. Pollut. 159, 1307-1316. doi: 10.1016/j.envpol.2011.01.023

Economist. (2013). Available online at: http://www.economist.com/news/scienceand-technology/21571386 [Accessed].

Eggersdorfer, B., and Häder, D.-P. (1991). Phototaxis, gravitaxis and vertical migrations in the marine dinoflagellates, Peridinium faeroense and Amphidinium caterea. Acta Protozool. 30, 63-71.

Egorova, T., Rozanov, E., Gröbner, J., Hauser, M., and Schmutz, W. (2013). Montreal Protocol benefits simulated with CCM SOCOL. Atmosph. Chem. Phys. 13, 3811-3823. doi: 10.5194/acp-13-3811-2013

Ekelund, N. G. A. (1994). Influence of UV-B radiation on photosynthetic light-response curves, absorption spectra and motility of four phytoplankton species. Physiol. Plant. 91, 696-702. doi: 10.1111/j.1399-3054.1994. tb03007.x

El-Sheekh, M. M., El-Naggar, A. H., Osman, M. E., and Haieder, A. (2000). Comparative studies on the green algae Chlorella homosphaera and Chlorella vulgaris with respect to oil pollution in the river Nile. Water Air Soil Pollut. 124, 187-204. doi: 10.1023/A:1005268615405

Fabricius, K. E., De'ath, G., Humphrey, C., Zagorskis, I., and Schaffelke, B. (2013). Intra-annual variation in turbidity in response to terrestrial runoff on nearshore coral reefs of the Great Barrier Reef. Estuar. Coast. Shelf Sci. 116, 57-65. doi: 10.1016/j.ecss.2012.03.010

Falkowski, P., Scholes, R. J., Boyle, E., Canadell, J., Canfield, D., Elser, J., et al. (2000). The global carbon cycle: a test of our knowledge of Earth as a system. Science 290, 291-296. doi: 10.1126/science.290.5490.291

Feely, R. A., Sabine, C. L., Lee, K., Berelson, W., Kleypas, J., Fabry, V. J., et al. (2004). Impact of anthropogenic $\mathrm{CO}_{2}$ on the $\mathrm{CaCO}_{3}$ system in the oceans. Science 305, 362-366. doi: 10.1126/science.1097329

Feng, S., Zhang, Y. L., and Qin, B. Q. (2006). Photochemical degradation of chromophoric dissolved organic matter in Meiliang Bay of Lake Taihu. China Environ. Sci. 26, 404-408.

Feng, Y., Hare, C. E., Leblanc, K., Rose, J. M., Zhang, Y., Ditullio, G. R., et al. (2009). Effects of increased $\mathrm{pCO}_{2}$ and temperature on the North Atlantic spring bloom. I. The phytoplankton community and biogeochemical response. Mar. Ecol. Prog. Ser. 388, 13-25. doi: 10.3354/meps08133

Feng, Y., Warner, M. E., Zhang, Y., Sun, J., Fu, F.-X., Rose, J. M., et al. (2008). Interactive effects of increased $\mathrm{pCO}_{2}$, temperature and irradiance on the marine coccolithophore Emiliania huxleyi (Prymnesiophyceae). Eur. J. Phycol. 43, 87-98. doi: 10.1080/09670260701664674

Fernandes, T. B., De Sa Azevedo, W. C., and Pedrosa, P. (2008). Sazonalidade óptica nas águas do rio Paraíba do Sul (Campos dos Goytacezes, RJ): referenciais métricos para o monitoramento de águas naturais? Oecol. Brasil. 12, 78-84.

Fichot, C., Kaiser, K., Hooker, B., Amon, R. M. W. IV., Marcel Babin, M., Simon, S., et al. (2013). Pan-Arctic distributions of continental runoff in the Arctic Ocean. Sci. Rep. 3:1053. doi: 10.1038/srep01053

Fiorini, S., Middelburg, J. J., and Gattuso, J.-P. (2011). Effects of elevated $\mathrm{CO}_{2}$ partial pressure and temperature on the coccolithophore Syracosphaera pulchra. Aquat. Microb. Ecol. 64, 221-232. doi: 10.3354/ame01520

Fischetti, M. (2013). Deep heat threatens marine life. Sci. Am. 308:92. doi: 10.1038/scientificamerican0413-92

Flynn, K. J., Blackford, J. C., Baird, M. E., Raven, J. A., Clark, D. R., Beardall, J., et al. (2012). Changes in $\mathrm{pH}$ at the exterior surface of plankton with ocean acidification. Nat. Clim. Change 2, 1-4. doi: 10.1038/nclimate1696

Forsström, L. (2006). Phytoplankton Ecology of Subarctic Lakes in Finnish Lapland. Ph.D., University of Helsinki.

Fu, F. X., Tatters, A. O., and Hutchins, D. A. (2012). Global change and the future of harmful algal blooms in the ocean. Mar. Ecol. Prog. Ser. 470, 207-233. doi: 10.3354/meps 10047

Fu, F. X., Warner, M. E., Zhang, Y., Feng, Y., and Hutchins, D. A. (2007). Effects of increased temperature and $\mathrm{CO}_{2}$ on photosynthesis, growth, and elemental ratios in marine Synechococcus and Prochlorococcus (Cyanobacteria). J. Phycol. 43, 485-496. doi: 10.1111/j.1529-8817.2007.00355.x

Fu, F.-X., Yu, E., Garcia, N. S., Gale, J., Luo, Y., Webb, E. A., et al. (2014). Differing responses of marine $\mathrm{N}_{2}$ fixers to warming and consequences for future diazotroph community structure. Aquat. Microb. Ecol. 72, 33-46. doi: 10.3354/ame01683

Galbán-Malagón, C. J., Cabrerizo, A., Berrojálbiz, N., Ojeda, M. J., and Dachs, J. (2012). Air-Water Exchange and Phytoplankton Accumulation of Persistent Organic Pollutants in the Greenland Current and Arctic Ocean [Online]. Available online at: http://132.246.11.198/2012-ipy/pdf-all/ipy2012arAbstract00801.pdf [Accessed].

Gang, N. J. Y., and Xitao, L. (2005). Advances in photolysis of persistent organic pollutants in water. Prog. Chem. 17, 938-948.

Gao, K., and Campbell, D. (2014). Photophysiological responses of marine diatoms to elevated $\mathrm{CO}_{2}$ and decreased $\mathrm{pH}$ : a review. Funct. Plant Biol. 41, 449-459. doi: 10.1071/FP13247

Gao, K., Helbling, E. W., Häder, D.-P., and Hutchins, D. A. (2012a). Responses of marine primary producers to interactions between ocean acidification, solar radiation, and warming. Mar. Ecol. Prog. Ser. 470, 167-189. doi: 10.3354/meps 10043

Gao, K., Xu, J., Gao, G., Li, Y., Hutchins, D. A., Huang, B., et al. (2012b). Rising $\mathrm{CO}_{2}$ and increased light exposure synergistically reduce marine primary productivity. Nat. Clim. Change 2, 519-523. doi: 10.1038/nclimate1507

Gerofke, A., Kömp, P., and McLachlan, M. S. (2005). Bioconcentration of persistent organic pollutants in four species of marine phytoplankton. Environ. Toxicol. Chem. 24, 2908-2917. doi: 10.1897/04-566R.1

Grenvald, J., Nielsen, T., and Hjorth, M. (2013). Effects of pyrene exposure and temperature on early development of two co-existing Arctic copepods. Ecotoxicology 22, 184-198. doi: 10.1007/s10646-012-1016-y

Gruber, N., Gloor, M., Fletcher, S. E. M., Doney, S. C., Dutkiewicz, S., Follows, M. J., et al. (2009). Oceanic sources, sinks, and transport of atmospheric $\mathrm{CO}_{2}$. Glob. Biogeochem. Cycles 23, GB1005. doi: 10.1029/2008GB003349

Häder, D.-P., and Griebenow, K. (1988). Orientation of the green flagellate, Euglena gracilis, in a vertical column of water. FEMS Microbiol. Ecol. 53, 159-167. doi: 10.1111/j.1574-6968.1988.tb02660.x

Häder, D.-P., Helbling, E. W., Williamson, C. E., and Worrest, R. C. (2011). Effects of UV radiation on aquatic ecosystems and interactions with climate change. Photochem. Photobiol. Sci. 10, 242-260. doi: 10.1039/c0pp $90036 \mathrm{~b}$

Häder, D.-P., Lebert, M., Schuster, M., Del Ciampo, L., Helbling, E. W., and McKenzie, R. (2007). ELDONET-a decade of monitoring solar radiation on five continents. Photochem. Photobiol. 83, 1348-1357. doi: 10.1111/j.17511097.2007.00168.x

Hallegraeff, G. M. (2010). Ocean climate change, phytoplankton community responses, and harmful algal blooms: a formidable predictive challenge. $J$. Phycol. 46, 220-235. doi: 10.1111/j.1529-8817.2010.00815.x

Halpern, B. S., Walbridge, S., Selkoe, K. A., Kappel, C. V., Micheli, F., D’Agrosa, C., et al. (2008). A global map of human impact on marine ecosystems. Science 319, 948-952. doi: 10.1126/science.1149345

Harada, H., Vila-Costa, M., Cebrian, J., and Kiene, R. P. (2009). Effects of $\mathrm{UV}$ radiation and nitrate limitation on the production of biogenic sulfur compounds by marine phytoplankton. Aquat. Bot. 90, 37-42. doi: 10.1016/j.aquabot.2008.05.004

Hare, C. E., Leblanc, K., Ditullio, G. R., Kudela, R. M., Zhang, Y., Lee, P. A., et al. (2007). Consequences of increased temperature and $\mathrm{CO}_{2}$ for phytoplankton community structure in the Bering Sea. Mar. Ecol. Prog. Ser. 352, 9-16. doi: $10.3354 /$ meps07182

Hargreaves, B. R., Girdner, S. F., Buktenica, M. W., Collier, R. W., Urbach, E., and Larson, G. L. (2007). Ultraviolet radiation and bio-optics in Crater Lake, Oregon. Hydrobiologia 574, 107-140. doi: 10.1007/s10750-006-0348-0

Hayakawa, K., and Sugiyama, Y. (2008). Spatial and seasonal variations in attenuation of solar ultraviolet radiation in Lake Biwa, Japan. J. Photochem. Photobiol. B 90, 121-133. doi: 10.1016/j.jphotobiol.2007.11.008

Heck, D. E., Vetrano, A. M., Mariano, T. M., and Laskin, J. D. (2003). UVB light stimulates production of reactive oxygen species. Unexpected role for catalase. J. Biol. Chem. 278, 22432-22436. doi: 10.1074/jbc.C3000 48200

Helbling, E. W., Barbieri, E. S., Marcoval, M. A., Gonçalves, R. J., and Villafañe, V. E. (2005). Impact of solar ultraviolet radiation on marine phytoplankton of Patagonia, Argentina. Photochem. Photobiol. 81, 807-818. doi: 10.1562/2005-0302-RA-452R.1

Helbling, E. W., Buma, A. G. J., Van De Poll, W., Fernández Zenoff, M. V., and Villafañe, V. E. (2008). UVR-induced photosynthetic inhibition dominates over 
DNA damage in marine dinoflagellates exposed to fluctuating solar radiation regimes. J. Exp. Mar. Biol. Ecol. 365, 96-102. doi: 10.1016/j.jembe.2008.07.044

Helbling, E. W., Gao, K., Gonçalves, R. J., Wu, H., and Villafañe, V. E. (2003). Utilization of solar UV radiation by coastal phytoplankton assemblages off SE China when exposed to fast mixing. Mar. Ecol. Prog. Ser. 259, 59-66. doi: 10.3354/meps259059

Hennon, G. M., Quay, P., Morales, R. L., Swanson, L. M., and Virginia Armbrust, E. (2014). Acclimation conditions modify physiological response of the diatom Thalassiosira pseudonana to elevated $\mathrm{CO}_{2}$ concentrations in a nitrate-limited chemostat. J. Phycol. 50, 243-253. doi: 10.1111/jpy.12156

Hinder, S. L., Hays, G. C., Edwards, M., Roberts, E. C., Walne, A. W., and Gravenor, M. B. (2012). Changes in marine dinoflagellate and diatom abundance under climate change. Nat. Clim. Change 2, 271-275. doi: 10.1038/nclimate1388

Hoffmann, L., Hoppe, C., Müller, R., Dutton, G., Gille, J., Griessbach, S., et al. (2014). Stratospheric lifetime ratio of CFC-11 and CFC-12 from satellite and model climatologies. Atmosph. Chem. Phys. 14, 12479-12497. doi: 10.5194/acp14-12479-2014

Howarth, R., Chan, F., Conley, D. J., Garnier, J., Doney, S. C., Marino, R., et al. (2011). Coupled biogeochemical cycles: eutrophication and hypoxia in temperate estuaries and coastal marine ecosystems. Front. Ecol. Environ. 9, 18-26. doi: $10.1890 / 100008$

Huang, Y.-J., Jiang, Z.-B., Zeng, J.-N., Chen, Q.-Z., Zhao, Y.-Q., Liao, Y.-B., et al. (2011). The chronic effects of oil pollution on marine phytoplankton in a subtropical bay, China. Environ. Monit. Assess. 176, 517-530. doi: 10.1007/s10661-010-1601-6

Huertas, I. E., Rouco, M., López-Rodas, V., and Costas, E. (2011). Warming will affect phytoplankton differently: evidence through a mechanistic approach. Proc. R. Soc. B 278, 3534-3543. doi: 10.1098/rspb.2011.0160

Hulatt, C. J., Thomas, D. N., Bowers, D. G., Norman, L., and Zhang, C. (2007). Exudation and decomposition of chromophoric dissolved organic matter (CDOM) from some temperate macroalgae. Estuar. Coast. Shelf Sci. 84, 147-153. doi: 10.1016/j.ecss.2009.06.014

Hutchins, D. A., Fu, F.-X., Webb, E. A., Walworth, N., and Tagliabue, A. (2013). Taxon-specific response of marine nitrogen fixers to elevated carbon dioxide concentrations. Nat. Geosci. 6, 790-795. doi: 10.1038/ngeo1858

Hutchins, D., Fu, F.-X., Zhang, Y., Warner, M. E., Feng, Y., Portune, K., et al. (2007). $\mathrm{CO}_{2}$ control of Trichodesmium $\mathrm{N}_{2}$ fixation, photosynthesis, growth rates, and elemental ratios: implications for past, present, and future ocean biogeochemistry. Limnol. Oceanogr. 52, 1293-1304. doi: 10.4319/lo.2007.52.4.1293

Hutchins, M., Johnson, A., Deflandre-Vlandas, A., Comber, S., Posen, P., and Boorman, D. (2010). Which offers more scope to suppress river phytoplankton blooms: reducing nutrient pollution or riparian shading? Sci. Tot. Environ. 408, 5065-5077. doi: 10.1016/j.scitotenv.2010.07.033

Hylander, S., Grenvald, J. C., and Kiørboe, T. (2014). Fitness costs and benefits of ultraviolet radiation exposure in marine pelagic copepods. Funct. Ecol. 28, 149-158. doi: 10.1111/1365-2435.12159

Ioki, M., Takahashi, S., Nakajima, N., Fujikura, K., Tamaoki, M., Saji, H., et al. (2008). An unidentified ultraviolet-B-specific photoreceptor mediates transcriptional activation of the cyclobutane pyrimidine dimer photolyase gene in plants. Planta 229, 25-36. doi: 10.1007/s00425-008-0803-4

Jin, P., Gao, K., Villafañe, V., Campbell, D., and Helbling, W. (2013). Ocean acidification alters the photosynthetic responses of a coccolithophorid to fluctuating ultraviolet and visible radiation. Plant Physiol. 162, 2084-2094. doi: 10.1104/pp.113.219543

Johnson, Z. I., Wheeler, B. J., Blinebry, S. K., Carlson, C. M., Ward, C. S., and Hunt, D. E. (2013). Dramatic variability of the carbonate system at a temperate coastal ocean site (Beaufort, North Carolina, USA) Is regulated by physical and biogeochemical processes on multiple timescales. PLoS ONE 8:e85117. doi: 10.1371/journal.pone.0085117

Josef, K., Saranak, J., and Foster, K. W. (2005). Ciliary behavior of a negatively phototactic Chlamydomonas reinhardtii. Cell Motil. Cytoskeleton 61, 97-111. doi: $10.1002 / \mathrm{cm} .20069$

Kahru, M., Brotas, V., Manzano-Sarabia, B., and Mitchell, B. G. (2010). Are phytoplankton blooms occurring earlier in the Arctic? Glob. Change Biol. 17, 1733-1739. doi: 10.1111/j.1365-2486.2010.02312.x

Kaiser, K. L. (2014). The Carbon Cycle and Royal Society Math. London: Principia Scientific International.

Keller, W. B., Heneberry, J., Leduc, J., Gunn, J., and Yan, N. (2006). Variations in epilimnion thickness in small boreal shield lakes: relationships with transparency, weather and acidification. Environ. Monit. Assess. 115, 419-431. doi: $10.1007 / \mathrm{s} 10661-006-7237-\mathrm{x}$

Kim, J.-H. (2006). The effect of seawater $\mathrm{CO}_{2}$ concentration on growth of a natural phytoplankton assemblage in a controlled mesocosm experiment. Limnol. Oceanogr. 51, 1629-1636. doi: 10.4319/lo.2006.51.4.1629

King, A. L., Sanudo-Wilhelmy, S. A., Leblanc, K., Hutchins, D. A., and Fu, F. (2011). $\mathrm{CO}_{2}$ and vitamin $\mathrm{B}_{12}$ interactions determine bioactive trace metal requirements of a subarctic Pacific diatom. ISME J. 5, 1388-1396. doi: 10.1038/ismej. 2010.211

Labry, C., Delmas, D., and Herbland, A. (2005). Phytoplankton and bacterial alkaline phosphatase activities in relation to phosphate and DOP availability within the Gironde plume waters (Bay of Biscay). J. Exp. Mar. Biol. Ecol. 318, 213-225. doi: 10.1016/j.jembe.2004.12.017

Langer, G., Geisen, M., Baumann, K.-H., Kläs, J., Riebesell, U., Thoms, S., et al. (2006). Species-specific responses of calcifying algae to changing seawater carbonate chemistry. Geochem. Geophy. Geosyst. 7, Q09006. doi: 10.1029/2005GC001227

Langer, G., Nehrke, G., Probert, I., Ly, J., and Ziveri, P. (2009). Strain-specific responses of Emiliania huxleyi to changing seawater carbonate chemistry. Biogeosciences 6, 2637-2646. doi: 10.5194/bg-6-2637-2009

Laufkoetter, C., Vogt, M., and Gruber, N. (2013). "Trends in marine plankton composition and export production in a CCSM-BEC hindcast (1960-2006)," in EGU General Assembly Conference Abstracts (Vienna), 11917.

Law, K. S., Sturges, W. T., Blake, D. R., Blake, N. J., Burkholder, J. B., Butler, J. H., et al. (2007). Halogenated Very Short-Lived Substances, Scientific Assessment of Ozone Depletion: 2006, Report No. 50, Chapter 2. Global Ozone Research and Monitoring Project. WMO (World Meteorological Organization), Geneva, 50: $2.1-2.57$.

Lawrimore, J. H., Menne, M. J., Gleason, B. E., Williams, C. N., Wuertz, D. B., Vose, R. S., et al. (2011). An overview of the Global Historical Climatology Network monthly mean temperature data set, version 3. J. Geophys. Res. (1984-2012) 116. doi: 10.1029/2011JD016187

Lebert, M., Richter, P., Porst, M., and Häder, D.-P. (1996). “Mechanism of gravitaxis in the flagellate Euglena gracilis," in Proceedings of the 12th C.E.B.A.S. Workshops. Annual Issue 1996, Bochum, ed R. Bräucker (Bochum: Ruhr-University of Bochum), 225-234.

Lenci, F., Colombetti, G., and Häder, D.-P. (1983). Role of flavin quenchers and inhibitors in the sensory transduction of the negative phototaxis in the flagellate, Euglena gracilis. Curr. Microbiol. 9, 285-290. doi: 10.1007/BF01 567202

Levitan, O., Kranz, S. A., Spungin, D., Prášil, O., Rost, B., and Berman-Frank, I. (2010). Combined effects of $\mathrm{CO}_{2}$ and light on the $\mathrm{N}_{2}$-fixing cyanobacterium Trichodesmium IMS101: a mechanistic view. Plant Physiol. 154, 346-356. doi: 10.1104/pp.110.159285

Lewandowska, A. M., Boyce, D. G., Hofmann, M., Matthiessen, B., Sommer, U., and Worm, B. (2014). Effects of sea surface warming on marine plankton. Ecol. Lett. 17, 614-623. doi: 10.1111/ele.12265

Lewandowska, A., and Sommer, U. (2010). Climate change and the spring bloom: a mesocosm study on the influence of light and temperature on phytoplankton and mesozooplankton. Mar. Ecol. Prog. Ser. 405, 101-111. doi: 10.3354/meps08520

Li, Y., Gao, K., Villafañe, V., and Helbling, E. (2012). Ocean acidification mediates photosynthetic response to UV radiation and temperature increase in the diatom Phaeodactylum tricornutum. Biogeosci. Dis. 9, 7197-7226. doi: 10.5194/bgd-9-7197-2012

Lindley, D. (1988). CFCs cause part of global ozone decline. Nature 332, 293. doi: $10.1038 / 332293 \mathrm{~b} 0$

Llewellyn, C. A., White, D. A., Martinez-Vincente, V., Tarran, G., and Smyth, T. J. (2012). Distribution of mycosporine-like amino acids along a surface water meridional transect of the Atlantic. Microb. Ecol. 64, 320-333. doi: 10.1007/s00248-012-0038-6

Low-Décarie, E., Fussmann, G. F., and Bell, G. (2011). The effect of elevated $\mathrm{CO}_{2}$ on growth and competition in experimental phytoplankton communities. Glob. Change Biol. 17, 2525-2535. doi: 10.1111/j.1365-2486.2011. 02402.x

Ma, Z., and Gao, K. (2009). Photosynthetically active and UV radiation act in an antagonistic way in regulating buoyancy of Arthrospira (Spirulina) platensis (cyanobacterium). Environ. Exp. Bot. 66, 265-269. doi: 10.1016/j.envexpbot.2009.02.006 
Mathivanan, V., Vijayan, P., Sabhanayakam, S., and Jeyachitra, O. (2007). An assessment of plankton population of Cauvery river with reference to pollution. $J$. Environ. Biol. 28, 523-526.

Matsunaga, S., Watanabe, S., Sakaushi, S., Miyamura, S., and Hori, T. (2003). Screening effect diverts the swimming directions from diaphototactic to positive phototactic in a disk-shaped green flagellate Mesostigma viride. Photochem. Photobiol. 77, 324-332. doi: 10.1562/0031-8655(2003)077<0324: SEDTSD $>2.0 . \mathrm{CO} ; 2$

Matsuoka, T. (1983). Negative phototaxis in Blepharisma japonicum. J. Protozool. 30, 409-414. doi: 10.1111/j.1550-7408.1983.tb02940.x

Matthews, J. A. (2013). Encyclopedia of Environmental Change: Three Volume Set. Los Angeles, CA: Sage.

Mayer, L. M., Schick, L. L., Skorko, K., and Boss, E. (2006). Photodissolution of particulate organic matter from sediments. Limnol. Oceanogr. 51, 1064-1071. doi: 10.4319/lo.2006.51.2.1064

McKenzie, R. L., Aucamp, P. J., Bais, A. F., Björn, L. O., Ilyas, M., and Madronich, S. (2011). Ozone depletion and climate change: impacts on UV radiation. Photochem. Photobiol. Sci. 10, 182-198. doi: 10.1039/c0pp90034f

Meador, J. A., Baldwin, A. J., Catala, P., Jeffrey, W. H., Joux, F., Moss, J. A., et al. (2009). Sunlight-induced DNA damage in marine micro-organisms collected along a latitudinal gradient from 70 degrees $\mathrm{N}$ to 68 degrees S. Photochem. Photobiol. 85, 412-421. doi: 10.1111/j.1751-1097.2008.00462.x

Meinshausen, M., Smith, S. J., Calvin, K., Daniel, J. S., Kainuma, M. L. T., Lamarque, J. F., et al. (2011). The RCP greenhouse gas concentrations and their extensions from 1765 to 2300. Clim. Change 109, 213-241. doi: 10.1007/s10584011-0156-z

Mericoa, A., Tyrrell, T., Lessard, E. J., Oguz, T., Stabeno, P. J., Zeeman, S., et al. (2004). Modelling phytoplankton succession on the Bering Sea shelf: role of climate influences and trophic interactions in generating Emiliania huxleyi blooms 1997-2000. Deep Sea Res. Part A I 51, 1803-1826. doi: 10.1016/j.dsr.2004.07.003

Mohovic, B., Gianesella, S. M. F., Laurion, I., and Roy, S. (2006). Ultraviolet Bphotoprotection efficiency of mesocosm-enclosed natural phytoplankton communities from different latitudes: Rimouski (Canada) and Ubatuba (Brazil). Photochem. Photobiol. 82, 952-961. doi: 10.1562/2005-09-30-RA-707

Mulholland, M. R., and Capone, D. G. (2000). The nitrogen physiology of the marine $\mathrm{N}_{2}$-fixing cyanobacteria Trichodesmium spp. Trends Plant Sci. 5, 148-153. doi: 10.1016/S1360-1385(00)01576-4

Müller, M., Lebrato, M., Riebesell, U., Schulz, K., Blanco-Ameijeiras, S., Sett, S., et al. (2014). Influence of temperature and $\mathrm{CO}_{2}$ on the strontium and magnesium composition of coccolithophore calcite. Biogeosciences 11, 1065-1075. doi: 10.5194/bg-11-1065-2014

Muller, R., Desel, C., Steinhoff, F. S., Wiencke, C., and Bischof, K. (2012). UVradiation and elevated temperatures induce formation of reactive oxygen species in gametophytes of cold-temperate/Arctic kelps (Laminariales, Phaeophyceae). Phycological Res. 60, 27-36. doi: 10.1111/j.1440-1835.2011.00630.x

Nelson, C. E., Goldberg, S. J., Kelly, L. W., Haas, A. F., Smith, J. E., Rohwer, F., et al. (2013). Coral and macroalgal exudates vary in neutral sugar composition and differentially enrich reef bacterioplankton lineages. ISME J. 7, 962-979. doi: 10.1038/ismej.2012.161

Oberholster, P. J., Botha, A. M., and Grobbelaar, J. U. (2004). Microcystis aeruginosa: source of toxic microcystins in drinking water. Afr. J. Biotechnol. 3, 159-168. doi: 10.5897/AJB2004.000-2029

Oberholster, P., Myburgh, J., Ashton, P., and Botha, A.-M. (2010). Responses of phytoplankton upon exposure to a mixture of acid mine drainage and high levels of nutrient pollution in Lake Loskop, South Africa. Ecotoxicol. Environ. Saf. 73, 326-335. doi: 10.1016/j.ecoenv.2009.08.011

Olguín, H. F., Puig, A., Loez, C. R., Salibián, A., Topalián, M. L., Castañé, P. M., et al. (2004). An integration of water physicochemistry, algal bioassays, phytoplankton, and zooplankton for ecotoxicological assessment in a highly polluted lowland river. Water Air Soil Pollut. 155, 355-381. doi: 10.1023/B:WATE.0000026538.51477.c2

Orr, J. C., Fabry, V. J., Aumont, O., Bopp, L., Doney, S. C., Feely, R. A., et al. (2005). Anthropogenic ocean acidification over the twenty-first century and its impact on calcifying organisms. Nature 437, 681-686. doi: 10.1038/nature 04095

Osburn, C. L., O'sullivan, D. W., and Boyd, T. J. (2009). Increases in the longwave photobleaching of chromophoric dissolved organic matter in coastal waters. Limnol. Oceanogr. 54, 145-159. doi: 10.4319/lo.2009.54.1.0145
Overmann, J., and Pfennig, N. (1992). Buoyancy regulation and aggregate formation in Amoebobacter purpureus from Mahoney Lake. FEMS Microbiol. Ecol. 101, 67-79. doi: 10.1016/0168-6496(92)90048-X

Pace, M., Reche, I., Cole, J., Fernández-Barbero, A., Mazuecos, I., and Prairie, Y. (2012). pH change induces shifts in the size and light absorption of dissolved organic matter. Biogeochemistry 108, 109-118. doi: 10.1007/s10533-011-9576-0 Palleiro, L., Rodríguez-Blanco, M., Taboada-Castro, M., and Taboada-Castro, M. (2013). The influence of discharge, $\mathrm{pH}$, dissolved organic carbon, and suspended solids on the variability of concentration and partitioning of metals in a rural catchment. Water Air Soil Pollut. 224, 1-11. doi: 10.1007/s11270-0131651-9

Paterson, A. M., Somers, K. M., Dillon, P. J., Heneberry, J., Keller, W. B., and Ford, A. (2008). Relationships between dissolved organic carbon concentrations, weather, and acidification in small Boreal Shield lakes. Can. J. Fish. Aquat. Sci. 65, 786-795. doi: 10.1139/f07-193

Paytan, A., Shellenbarger, G. G., Street, J. H., Gonneea, M. E., Davis, K., and Young, M. B. (2006). Submarine groundwater discharge: an important source of new inorganic nitrogen to coral reef ecosystems. Limnol. Oceanogr. 51, 343-348. doi: 10.4319/lo.2006.51.1.0343

Pelletier, A.., Sargian, P., Payet, J., and Demers, S. (2006). Ecotoxicological effects of combined UVB and organic contaminants in coastal waters: a review. Photochem. Photobiol. 82, 981-993. doi: 10.1562/2005-09-18-RA-688.1

Piazena, H., and Häder, D.-P. (1995). Vertical distribution of phytoplankton in coastal waters and its detection by backscattering measurements. Photochem. Photobiol. 62, 1027-1034. doi: 10.1111/j.1751-1097.1995.tb02404.x

Pittera, J., Humily, F., Thorel, M., Grulois, D., Garczarek, L., and Six, C. (2014). Connecting thermal physiology and latitudinal niche partitioning in marine Synechococcus. ISME J. 8, 1221-1236. doi: 10.1038/ismej.2013.228

Pörtner, H. O., and Farrell, A. P. (2008). Physiology and climate change. Science 322, 690-692. doi: 10.1126/science.1163156

Previdi, M., and Polvani, L. M. (2014). Climate system response to stratospheric ozone depletion and recovery. Q. J. R. Meteorol. Soc. 140, 2401-2419. doi: 10.1002/qj.2330

Ptacnik, R., Solimini, A. G., Andersen, T., Tamminen, T., Brettum, P., Lepist,ö, L., et al. (2008). Diversity predicts stability and resource use efficiency in natural phytoplankton communities. Proc. Natl. Acad. Sci. U.S.A. 105, 5134-5138. doi: 10.1073/pnas.0708328105

Qu, H. J., and Kroeze, C. (2012). Nutrient export by rivers to the coastal waters of China: management strategies and future trends. Reg. Environ. Change 12, 153-167. doi: 10.1007/s10113-011-0248-3

Rastogi, R. P., Sinha, R. P., and Incharoensakdi, A. (2013). Partial characterization, UV-induction and photoprotective function of sunscreen pigment, scytonemin from Rivularia sp. HKAR-4. Chemosphere 93, 1874-1878. doi: 10.1016/j.chemosphere.2013.06.057

Richa, Sinha, R. P., and Häder, D.-P. (2014). "Physiological aspects of UV-excitation of DNA," in Photoinduced Phenomena in Nucleic Acids, eds B. Barbatti, A. C. Borin, and A. C. Ullrich (Berlin; Heidelberg: Springer), 1-46.

Richter, P. R., Häder, D.-P., Goncalves, R. J., Marcoval, M. A., Villafañe, V. E., and Helbling, E. W. (2007). Vertical migration and motility responses in three marine phytoplankton species exposed to solar radiation. Photochem. Photobiol. 83, 810-817. doi: 10.1111/j.1751-1097.2007.00076.x

Riebesell, U., and Tortell, P. D. (2011). "Effects of ocean acidification on pelagic organisms and ecosystems," in Ocean Acidification, eds J. P. Gattuso and L. Hansson (Oxford: Oxford University Press), 99-116.

Roberts, A. M. (2006). Mechanisms of gravitaxis in Chlamydomonas. Biol. Bull. 210, 78-80. doi: 10.2307/4134597

Rose, K. C., Williamson, C. E., Schladow, S. G., Winder, M., and Oris, J. T. (2009). Patterns of spatial and temporal variability of UV transparency in Lake Tahoe, California-Nevada. J. Geophys. Res. 114, 1-9. doi: 10.1029/2008JG000816

Rossoll, D., Bermúdez, R., Hauss, H., Schulz, K. G., Riebesell, U., Sommer, U., et al. (2012). Ocean acidification-induced food quality deterioration constrains trophic transfer. PLOS ONE 7:e34737. doi: 10.1371/journal.pone. 0034737

Santos, A. M. J. (2010). Influence of Saharan Aerosols on Phytoplankton Biomass in the Tropical North Atlantic Ocean. Ph.D. thesis, University of Puerto Rico, Mayagüez Campus, Hoboken, NJ.

Schaum, E., Rost, B., Millar, A. J., and Collins, S. (2013). Variation in plastic responses of a globally distributed picoplankton species to ocean acidification. Nat. Clim. Change 3, 298-302. doi: 10.1038/nclimate1774 
Schindler, D. W., and Smol, J. P. (2006). Cumulative effects of climate warming and other human activities on freshwaters of Arctic and Subarctic North America. Ambio 35, 160-168. doi: 10.1579/0044-7447(2006)35[160:CEOCWA]2. $0 . \mathrm{CO} ; 2$

Schippers, P., Lürling, M., and Scheffer, M. (2004). Increase of atmospheric $\mathrm{CO}_{2}$ promotes phytoplankton productivity. Ecol. Lett. 7, 446-451. doi: 10.1111/j.1461-0248.2004.00597.x

Schouten, P. W., Parisi, A. V., and Turnbull, D. J. (2007). Evaluation of a high exposure solar UV dosimeter for underwater use. Photochem. Photobiol. 83, 931-937. doi: 10.1111/j.1751-1097.2007.00085.x

Schouten, P. W., Parisi, A. V., and Turnbull, D. J. (2009). Applicability of the polyphenylene oxide film dosimeter to high UV exposures in aquatic environments. J. Photochem. Photobiol B 96, 184-192. doi: 10.1016/j.jphotobiol.2009.06.007

Seckmeyer, G., Glandorf, M., Wichers, C., McKenzie, R. L., Henriques, D., Carvalho, F., et al. (2008). Europe's darker atmosphere in the UV-B. Photochem. Photobiol. Sci. 7, 925-930. doi: 10.1039/b804109a

Seguin, F., Le Bihan, F., Leboulanger, C., and Bérard, A. (2002). A risk assessment of pollution: induction of atrazine tolerance in phytoplankton communities in freshwater outdoor mesocosms, using chlorophyll fluorescence as an endpoint. Water Res. 36, 3227-3236. doi: 10.1016/S0043-1354(02)00013-1

Sett, S., Bach, L. T., Schulz, K. G., Koch-Klavsen, S., Lebrato, M., and Riebesell, U. (2014). Temperature modulates coccolithophorid sensitivity of growth, photosynthesis and calcification to increasing seawater $\mathrm{pCO}_{2}$. PLoS ONE 9:e88308. doi: 10.1371/journal.pone.0088308

Shashi Shekhar, T., Kiran, B., Puttaiah, E., Shivaraj, Y., and Mahadevan, K. (2008). Phytoplankton as index of water quality with reference to industrial pollution. J. Environ. Biol. 29, 233-236.

Shiller, A. M., Duan, S., Van Erp, P., and Bianchi, T. S. (2006). Photo-oxidation of dissolved organic matter in river water and its effect on trace element speciation. Limnol. Oceanogr. 51, 1716-1728. doi: 10.4319/lo.2006.51.4.1716

Sigman, D. M., Hain, M. P., and Haug, G. H. (2010). The polar ocean and glacial cycles in atmospheric $\mathrm{CO}_{2}$ concentration. Nature 466, 47-55. doi: 10.1038/nature09149

Singh, S. P., Kumari, S., Rastogi, R. P., Singh, K. L., and Sinha, R. P. (2008). Mycosporine-like amino acids (MAAs): chemical structure, biosynthesis and significance as UV-absorbing/screening compounds. Indian J. Exp. Biol. 46, 7-17.

Sinha, R. P., Barbieri, E. S., Lebert, M., Helbling, E. W., and Häder, D.-P. (2003). Effects of solar radiation on phycobiliproteins of marine red algae. Trends Photochem. Photobiol. 10, 149-157.

Sinha, R. P., and Häder, D.-P. (2003). Biochemistry of phycobilisome disassembly by ultraviolet-B radiation in cyanobacteria. Rec. Res. Dev. Biochem. 4, 945-955.

Sinha, R. P., Klisch, M., and Häder, D.-P. (1999). Induction of a mycosporinelike amino acid (MAA) in the rice-field cyanobacterium Anabaena sp. by UV irradiation. J. Photochem. Photobiol. B 52, 59-64. doi: 10.1016/S10111344(99)00103-7

Sinha, R. P., Kumar, A., Tyagi, M. B., and Häder, D.-P. (2005). Ultraviolet-Binduced destruction of phycobiliproteins in cyanobacteria. Physiol. Mol. Biol. Plants 11, 313-319.

Sinha, R. P., Singh, S. P., and Häder, D.-P. (2008). Effects of UV-B radiation on phytoplankton and macroalgae: adaptation strategies. Proc. Natl. Acad. Sci. India B $78,105-116$.

Six, C., Joubin, L., Partensky, F., Holtzendorff, J., and Garczarek, L. (2007). UV-induced phycobilisome dismantling in the marine picocyanobacterium Synechococcus sp. WH8102. Photosyn. Res. 92, 75-86. doi: 10.1007/s11120-0079170-4

Smith, R. C., and Mobley, C. D. (2007). "Underwater light," in Photobiology. The Science of Life and Light. 2nd Edn., ed L. O. Björn (New York, NY: Springer), 131-138.

Solomon, S. (ed.). (2007). Climate Change 2007-The Physical Science Basis: Working Group I. Cambridge, MA: Cambridge University Press.

Sommaruga, R., and Augustin, G. (2006). Seasonality in UV transparency of an alpine lake is associated to changes in phytoplankton biomass. Aquat. Sci. 68, 129-141. doi: 10.1007/s00027-006-0836-3

Staehr, P. A., and Sand-Jensen, K. (2006). Seasonal changes in temperature and nutrient control of photosynthesis, respiration and growth of natural phytoplankton communities. Freshw. Biol. 51, 249-262. doi: 10.1111/j.13652427.2005.01490.x
Suhett, A. L., Amado, A. M., Enrich-Prast, A., De Assis Esteves, F., and Farjalla, V. F. (2007). Seasonal changes of dissolved organic carbon photo-oxidation rates in a tropical humic lagoon: the role of rainfall as a major regulator. Can. J. Fish. Aquat. Sci. 64, 1266-1272. doi: 10.1139/f07-103

Tardent, P. (2005). Meeresbiologie, Eine Einführung. Stuttgart: Thieme.

Tedetti, M., Joux, F., Charriere, B., Mopper, K., and Sempere, R. (2009). Contrasting effects of solar radiation and nitrates on the bioavailability of dissolved organic matter to marine bacteria. J. Photochem. Photobiol. A 201, 243-247. doi: 10.1016/j.jphotochem.2008.11.002

Tedetti, M., Sempere, R., Vasilkov, A., Charriere, B., Nerini, D., Miller, W. L., et al. (2007). High penetration of ultraviolet radiation in the south east Pacific waters. Geophys. Res. Lett. 34, L126101-L126105. doi: 10.1029/2007GL029823

Thomas, M. K., Kremer, C. T., Klausmeier, C. A., and Litchman, E. (2012). A global pattern of thermal adaptation in marine phytoplankton. Science 338, 1085-1088. doi: 10.1126/science. 1224836

Thyssen, M., Ferreyra, G., Moreau, S., Schloss, I., Denis, M., and Demers, S. (2011). The combined effect of ultraviolet $B$ radiation and temperature increase on phytoplankton dynamics and cell cycle using pulse shape recording flow cytometry. J. Exp. Mar. Biol. Ecol. 406, 95-107. doi: 10.1016/j.jembe.2011.06.015

Tortell, P. D. (2000). Evolutionary and ecological perspectives on carbon acquisition in phytoplankton. Limnol. Oceanogr. 45, 744-750. doi: 10.4319/lo.2000.45.3.0744

Tzortziou, M., Osburn, C. L., and Neale, P. J. (2007). Photobleaching of dissolved organic material from a tidal marsh-estuarine system of the Chesapeake Bay. Photochem. Photobiol. 83, 782-792. doi: 10.1111/j.1751-1097.2007.00142.x

Ungar, S. (2012). Ozone Depletion. Hoboken, NJ: Wiley.

United Nations Environment Programme Environmental Effects Assessment Panel. (2012). Environmental effects of ozone depletion and its interactions with climate change: progress report, 2011. Photochem. Photobiol. Sci. 11, 13-27. doi: 10.1039/clpp90033a

Vahatalo, A. V., and Jarvinen, M. (2007). Photochemically produced bioavailable nitrogen from biologically recalcitrant dissolved organic matter stimulates production of a nitrogen-limited microbial food web in the Baltic Sea. Limnol. Oceanogr. 52, 132-143. doi: 10.4319/lo.2007.52.1.0132

Vione, D., Lauri, V., Minero, C., Maurino, V., Malandrino, M., Carlotti, M. E., et al. (2009). Photostability and photolability of dissolved organic matter upon irradiation of natural water samples under simulated sunlight. Aquat. Sci. 71, 34-45. doi: $10.1007 /$ s00027-008-8084-3

Walczak, M. (2008). Impact of solar radiation, including UV, on the activity of intra- and extracellular bacterial enzymes from the surface microlayer. Pol. J. Nat. Sci. 23, 415-427. doi: 10.2478/v10020-008-0032-0

Waldbusser, G. G., and Salisbury, J. E. (2014). Ocean acidification in the coastal zone from an organism's perspective: multiple system parameters, frequency domains, and habitats. Ann. Rev. Mar. Sci. 6, 221-247. doi: 10.1146/annurevmarine-121211-172238

Walsby, A. E. (1987). "Mechanisms of buoyancy regulation by planktonic cyanobacteria with gas vesicles," in The Cyanobacteria, eds P. Fay and C. Van Baalen (Amsterdam: Elsevier Science Publishers), 385-392.

Wang, X., Lou, T., and Xie, H. (2009). Photochemical production of dissolved inorganic carbon from Suwannee river humic acid. Chin. J. Oceanol. Limnol. 27, 570-573. doi: 10.1007/s00343-009-9156-5

Wu, D., Hu, Q., Yan, Z., Chen, W., Yan, C., Huang, X., et al. (2012). Structural basis of ultraviolet-B perception by UVR8. Nature 484, 214-219. doi: 10.1038/nature10931

Wu, H. Y., Zou, D. H., and Gao, K. S. (2008). Impacts of increased atmospheric $\mathrm{CO}_{2}$ concentration on photosynthesis and growth of micro- and macro-algae. Sci. China Ser. C 51, 1144-1150. doi: 10.1007/s11427-008$0142-5$

Wu, Y., Gao, K., and Riebesell, U. (2010). $\mathrm{CO}_{2}$-induced seawater acidification affects physiological performance of the marine diatom Phaeodactylum tricornutum. Biogeosciences 7, 2915-2923. doi: 10.5194/bg-72915-2010

Xie, H. X., Belanger, S., Demers, S., Vincent, W. F., and Papakyriakou, T. N. (2009). Photobiogeochemical cycling of carbon monoxide in the southeastern Beaufort Sea in spring and autumn. Limnol. Oceanogr. 54, 234-249. doi: 10.4319/lo.2009.54.1.0234

$\mathrm{Xu}$, J., and Gao, K. (2012). Future $\mathrm{CO}_{2}$-induced ocean acidification mediates the physiological performance of a green tide alga. Plant Physiol. 160, 1762-1769. doi: $10.1104 /$ pp.112.206961 
Xu, K., Gao, K., Villafañe, V., and Helbling, E. (2011). Photosynthetic responses of Emiliania huxleyi to UV radiation and elevated temperature: roles of calcified coccoliths. Biogeosciences 8, 1441-1452. doi: 10.5194/bg-8-1441-2011

Yamashita, Y., Boyer, J. N., and Jaffe, R. (2013). Evaluating the distribution of terrestrial dissolved organic matter in a complex coastal ecosystem using fluorescence spectroscopy. Cont. Shelf Res. 66, 136-144. doi: 10.1016/j.csr.2013.06.010

Yang, G., and Gao, K. (2012). Physiological responses of the marine diatom Thalassiosira pseudonana to increased $\mathrm{pCO}_{2}$ and seawater acidity. Mar. Environ. Res. 79, 142-151. doi: 10.1016/j.marenvres.2012.06.002

Yoshiyama, K., and Nakajima, H. (2002). Catastrophic transition in vertical distributions of phytoplankton: alternative equilibria in a water column. J. Theor. Biol. 216, 397-408. doi: 10.1006/jtbi.2002.3007

Zepp, R. G., Erickson, D. J., Paul, N. D., and Sulzberger, B. (2007). Interactive effects of solar UV radiation and climate change on biogeochemical cycling. Photochem. Photobiol. Sci. 6, 286-300. doi: 10.1039/b700021a

Zhang, Y., Jiang, H.-B., and Qiu, B.-S. (2013). Effects of UVB radiation on competition between the bloom-forming cyanobacterium Microcystis aeruginosa and the chlorophyceae Chlamydomonas microsphaera. J. Phycol. 49, 318-328. doi: 10.1111/jpy.12038

Zhang, Y., Xie, H. X., Fichot, C. G., and Chen, G. H. (2008). Dark production of carbon monoxide (CO) from dissolved organic matter in the St. Lawrence estuarine system: implication for the global coastal and blue water CO budgets. J. Geophys. Res. Oceans 113, 9. doi: 10.1029/2008JC004811

Zhou, W., Yin, K., Yuan, X., and Ning, X. (2009). Comparison of the effects of short-term UVB radiation exposure on phytoplankton photosynthesis in the temperate Changjiang and subtropical Zhujiang estuaries of China. J. Oceanogr. 65, 627-638. doi: 10.1007/s10872-009-0053-5

Zou, D., Gao, K., and Luo, H. (2011). Short- and long-term effects of elevated $\mathrm{CO}_{2}$ on photosynthesis and respiration in the marine macroalga Hizikia fusiformis (Sargassaceae, Phaeophyta) grown at low and high N supplies. J. Phycol. 47, 87-97. doi: 10.1111/j.1529-8817.2010.00929.x

Conflict of Interest Statement: The Associate Editor Rajeshwar Sinha declares that, despite having published with the author Donat P. Häder in the last 2 years, the review process was handled objectively and no conflict of interest exists. The authors declare that the research was conducted in the absence of any commercial or financial relationships that could be construed as a potential conflict of interest.

Received: 08 October 2014; accepted: 14 February 2015; published online: 03 March 2015.

Citation: Häder D-P and Gao K (2015) Interactions of anthropogenic stress factors on marine phytoplankton. Front. Environ. Sci. 3:14. doi: 10.3389/fenvs.2015.00014

This article was submitted to Environmental Toxicology, a section of the journal Frontiers in Environmental Science.

Copyright (C) 2015 Häder and Gao. This is an open-access article distributed under the terms of the Creative Commons Attribution License (CC BY). The use, distribution or reproduction in other forums is permitted, provided the original author(s) or licensor are credited and that the original publication in this journal is cited, in accordance with accepted academic practice. No use, distribution or reproduction is permitted which does not comply with these terms. 